\title{
FACTORS GOVERNING THE NATURALIZATION-TO-INVASION TRANSITION OF EXOTIC PLANTS IN SHENZHEN, CHINA
}

\author{
DAI, X-K. ${ }^{1,2}-$ ZHU, R. ${ }^{3}-$ JIA, P. ${ }^{1}-$ SHEN, L. ${ }^{4}-$ LI, S-P. ${ }^{1}-$ HUA, Z-S. ${ }^{1}-$ LI, M-G. ${ }^{1,2}-$ LI, J-T. ${ }^{1, *}$ \\ ${ }^{1}$ State Key Laboratory of Biocontrol and Guangdong Provincial Key Laboratory of Plant \\ Resources, School of Life Sciences, Sun Yat-sen University, Guangzhou, Guangdong, People's \\ Republic of China \\ ${ }^{2}$ Urban Management Bureau of Shenzhen Municipality, No. 4 Lianhua Branch Road, Futian \\ District, Shenzhen, Guangdong, People's Republic of China \\ ${ }^{3}$ College of Civil and Environmental Engineering, Anhui Xinhua University, Hefei, Anhui, \\ People's Republic of China \\ ${ }^{4}$ School of Environmental Science and Engineering, Sun Yat-sen University, Guangzhou, \\ Guangdong, People's Republic of China \\ *Corresponding author \\ e-mail: lijtian@mail.sysu.edu.cn \\ (tel: +86-20-84111430; fax: +86-20-84111430) \\ (Received $17^{\text {th }}$ Sep 2015; accepted $4^{\text {th }}$ Jun 2016)
}

\begin{abstract}
Understanding factors increasing the probability of exotic plants becoming invasive is crucial for designing appropriate management strategies to mitigate the detrimental effects of invasive plants on rapidly urbanizing areas. However, no study to date has attempted to determine how various factors may affect the naturalization-to-invasion transition of exotic plants in these areas. Here, we took Shenzhen, one of the largest and most rapidly urbanizing cities of the world, as a case study to explore how various factors may affect the naturalization-to-invasion transition of exotic plants in rapidly urbanizing areas, with an emphasis on exotic plant invasion in urban forests. Our results showed that $33.5 \%$ of the 349 naturalized exotic plant species in Shenzhen have become invasive. We found strong evidence that plant attributes and environmental factors have considerable effects on the naturalization-to-invasion transition of exotic plant species in Shenzhen. In contrast, there was little evidence that any socio-economic factor promotes the naturalization-to-invasion transition of exotic plants in Shenzhen. Our findings suggested that although human activities facilitated the initial establishment of exotic plant species in rapidly urbanizing areas, the naturalization-to-invasion transition of exotic plants in these areas appeared to be governed largely by biotic and environmental factors.
\end{abstract}

Keywords: exotic plant invasion, determinants of naturalization-invasion transition, invasive plant, naturalized plant, urban forests

\section{Introduction}

Biological invasions by exotic species are a significant component of human-caused global environmental change (Vitousek et al., 1997). More than 2,000 exotic plant species have been recorded in the USA (Vitousek et al., 1997); this figure reaches 5,700 in Europe (Vilà et al., 2010). Furthermore, biological invasions can not only cause disastrous damage to native biodiversity and ecosystem functions (Vilà et al., 2011) but also seriously affect the development of economies and societies (Perrings et al., 2002). In China, biological invasions have been estimated to cause US\$ 14 billion worth of economic losses per year (Xu et al., 2006); a similar estimate for the USA reaches US\$ 120 billion (Pimentel et al., 2005). Thus, there is an urgent need to understand which 
combinations of species attributes and habitat characteristics most effectively promote or prevent exotic plant invasion (Kolar and Lodge, 2001; Romanuk et al., 2009).

Urbanization, a major global trend (United Nations Population Division, 2006), is always associated with the establishment of a large number of exotic plant species in urban habitats (Pauchard and Alaback, 2004), which can ultimately decrease the ecological, social and economic sustainability of cities. Given that over 50\% of the world's population now lives in cities (United Nations Population Division, 2016), a better understanding of patterns and drivers of exotic plant invasion in urban habitats is critical for the sustainability of not only cities but also the human population. Unfortunately, we have a relatively poor understanding of these aspects, largely because most previous research on exotic plant invasion has focused instead on natural or semi-natural habitats (McKinney, 2002; Pauchard et al., 2006; Spear et al., 2013).

Only a few studies have been performed to address the issue of exotic plant invasion in urban habitats (Celesti-Grapow et al., 2006; Dolan et al., 2011; Leung et al., 2009; Lososová et al., 2012; Pyšek, 1998; Ricotta et al., 2009; Ricotta et al., 2010; Wang et al., 2011). The invasiveness of exotic plant species in urban habitats was found to be related to their phylogenetic similarity to native plant species (Ricotta et al., 2010), and the species richness of exotic plants in cities was significantly affected by city size, habitat type and climate (Celesti-Grapow et al., 2006; Lososová et al., 2012; Pyšek, 1998). In addition, the number of naturalized and invasive plant species in a given district of a rapidly urbanizing city was found to be highly predicted by the economic growth of that district (Wang et al., 2011). These findings provide useful insights, but they are inadequate for developing appropriate management strategies to mitigate the detrimental effects of exotic plant invasions in cities experiencing rapid urbanization because none of the previous studies was focused on urban forest despite the fact that urban forest is a major type of habitat in cities. According to the definition proposed by Escobedo and colleagues, urban forests are the sum of all urban trees, shrubs, lawns, and pervious soils. Urban forests are generally considered as non-natural habitats, because they are located in highly altered ecosystems where humans are the main factors determining their types, amounts, and distribution (Escobedo et al., 2011). Unlike other urban habitats, such as roadsides, private gardens and parks (which can serve as important ways of exotic species introductions), urban forests are part of land use in cities (Escobedo et al., 2011; Dobbs et al., 2011). For example, urban forest currently accounts for $35.1 \%$ (Nowak et al., 2010) and 39.9\% (Chen and Wang, 2013) of land use in cities in the USA and China, respectively. However, there is emerging evidence that urban forests do not escape exotic plant invasion (Singh et al., 2015).

The transition from naturalization to invasion has been considered the most important step for exotic plant species becoming serious ecological, economic and social problems (Phillips et al., 2010; Williamson and Fitter, 1996), although the exotic plant invasion process is always an introduction-naturalization-invasion continuum (Richardson et al., 2000; Richardson and Pyšek, 2006). In this sense, a promising approach to improve our understanding of exotic plant invasion in urban habitats is to explore the transition from naturalization to invasion of exotic plants in urban forests and its driving factors. However, to date, no study has attempted to directly address this issue, which constitutes a critical gap in research on exotic plant invasion in urban habitats. According to the Tens Rule proposed by Williamson and Fitter (Williamson and Fitter, 1996), approximately $10 \%$ of the exotic plant species naturalized in urban habitats will become invasive. However, we would expect the real 
invasive-to-naturalized plant species richness ratios observed in urban habitats to be greater than $10 \%$ because urban habitats are generally exposed to higher propagule pressure from exotic plants, stronger human disturbances, and larger and more frequent resource fluctuations than those more natural habitats on which the Tens Rule was based (Lososová et al., 2012).

In this study, we took Shenzhen as a case study to explore how various factors may affect the naturalization-to-invasion transition of exotic plants in cities experiencing rapid urbanization, with an emphasis on plant invasion in urban forests. To this end, we first generated a comprehensive database of all naturalized and invasive exotic plant species in Shenzhen and then used it to assess the effects of the plants' attributes on their transition from naturalization to invasion. Additionally, we conducted a series of ecological field surveys on 19 major urban forests in Shenzhen to determine the effects of environmental and socio-economic factors on the naturalization-to-invasion transition of the exotic plant species found in urban forests. We considered Shenzhen to be fairly representative of other areas experiencing rapid urbanization, as it is one of the largest cities in the world and has been experiencing rapid urbanization over the past 30 years (McKinsey Global Institute, 2012).

\section{Materials and Methods}

\section{Study site}

Located in South China, Shenzhen is a natural port city and functions as a bridge between Hong Kong and mainland China (Fig. 1). As China's first special economic zone, it has experienced rapid urbanization over the past 30 years, and its gross domestic product (GDP) has been growing at an average annual rate higher than $20 \%$ over that period (Liu et al., 2007). In 2013, Shenzhen's GDP reached US\$ 234 billion, and its total population reached 10.5 million (Statistics Bureau of Shenzhen Municipality, 2013). Shenzhen also plays an important role in China's foreign trade, with a total import and export volume reaching US\$ 537 billion in 2013 (Statistics Bureau of Shenzhen Municipality, 2013). Although this rapid urbanization has increased people's wealth and improved their quality of life, it has also had significant environmental impacts (Liu et al., 2007). For example, Shenzhen has been considered one of the areas at highest risk of biological invasions in China (Wu et al., 2006), as indicated by the fact that the number of exotic species intercepted by the Shenzhen Entry-Exit Inspection and Quarantine Bureau in 2010 was as high as 981 (SEEIQB, 2010). Indeed, the number of exotic species in Shenzhen had reached 102 approximately ten years ago (Yan et al., 2004).

\section{Compilation of a database for naturalized and invasive plant species in Shenzhen}

In this study, the term 'naturalized species' was used according to the definition of Richardson et al. (Richardson et al., 2000), whereas the term 'invasive species' was used in the sense of McNeely et al. (McNeely et al., 2001). In brief, here, invasive plant species are a subset of naturalized exotic plant species that cause damage to species, habitats, or to the economy. The published literature addressing naturalized and invasive species in Shenzhen or in China (Yan et al., 2004; Feng and Zhu, 2010; Jiang et al., 2011; Xu and Qiang, 2011; Shao et al., 2006; Wan et al., 2012; Weber et al., 2008) was reviewed to generate a comprehensive database of the naturalized and invasive exotic 
plant species in Shenzhen. The major attributes (including taxonomic group, geographic origin and life form) of the exotic plant species were documented largely according to Flora of China (2013) and Flora of Shenzhen (Li and Li, 2010).

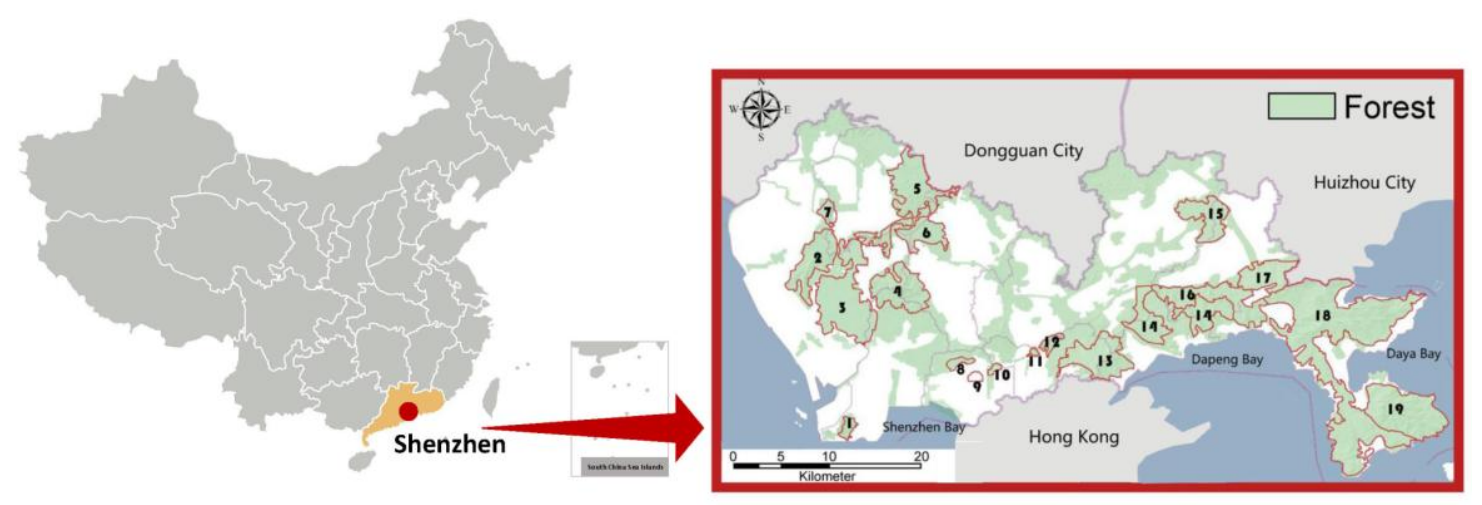

Figure 1. Map of the study sites. The bold Arabic numbers indicate 19 major urban forests, which were investigated to explore the effects of environmental and socio-economic factors on the naturalization-to-invasion transition of exotic plants in Shenzhen. Red curves show the edges of the studied forests. See Tables S1, S2 and S3 for more details. This figure was drawn based on two maps that are open to the public: the maps of China and Shenzhen can be accessed on http://www.sbsm.gov.cn/article/ zxbs/dtfw/ and http://www.szgeoinfo.com/szgeoinfo/default.htm, respectively.

\section{Ecological field surveys on 19 major urban forests of Shenzhen}

Forest is one of the most important types of urban land cover in Shenzhen (Fig. 1). Specifically, Shenzhen's urban forests cover 77,720.9 hectares, which account for $39.9 \%$ of Shenzhen Municipality's total area (Shenzhen statistics yearbook, 2013). To determine the effects of environmental and socio-economic factors on the naturalization-to-invasion transition of the exotic plants in urban forests, 19 important urban forests within Shenzhen were selected for surveying (Fig. 1). These forests are distributed across the city (Fig. 1) and their summed area accounts for $64.4 \%$ of the total forest area in the city (Table 1). During the ecological field surveys, data were collected from 217 plots, each having an area of $600 \mathrm{~m}^{2}(30 \mathrm{~m} \times 20 \mathrm{~m})$. The number of plots within each urban forest ranged from 4 to 19, depending largely on their area. Replicate plots for each forest were located largely along a specific altitudinal gradient, which was set according to the altitude of individual forests. Plots were typically established on a relatively gentle slope to facilitate access. In each plot, the identity of the plants was recorded and 5 soil samples were collected. The plant species list resulting from the field surveys was used to assess the number of naturalized and invasive exotic plant species in the individual forests. The soil samples were air-dried and used to determine the following physico-chemical properties (Schinner et al., 1996): $\mathrm{pH}$, density, porosity, moisture content, organic matter content, total nitrogen and available phosphorus (Table 1 and Table $S 1$ in Appendix). 
Table 1. Descriptive statistics of the environmental and socio-economic factors under consideration in this study.

\begin{tabular}{lllll}
\hline Factors* & Unit & Mean & Min & Max \\
\hline Environmental factors & & & & \\
Area & $\mathrm{ha}$ & 2,634 & 87.3 & 14,457 \\
Average altitude & $\mathrm{m}$ & 159 & 57.4 & 326 \\
Mean January temperature & ${ }^{\circ} \mathrm{C}$ & 13.6 & 9.8 & 14.4 \\
Mean July temperature & ${ }^{\circ} \mathrm{C}$ & 28.4 & 23.9 & 29.5 \\
Annual average precipitation & $\mathrm{mm}$ & 1,617 & 1,311 & 1,901 \\
Density of native plant species & $\mathrm{species} / \mathrm{ha}$ & 2.39 & 0.76 & 3.78 \\
Soil density & $\mathrm{g} / \mathrm{cm}^{3}$ & 1.32 & 0.82 & 1.86 \\
Soil porosity & $\%$ & 48.2 & 40.0 & 58.7 \\
Soil moisture & $\%$ & 11.0 & 1.32 & 24.3 \\
Soil pH & & 5.05 & 4.14 & 6.39 \\
Soil organic matter content & $\mathrm{g} / \mathrm{kg}$ & 14.3 & 5.51 & 38.0 \\
Soil total nitrogen content & $\mathrm{g} / \mathrm{kg}$ & 0.64 & 0.15 & 1.59 \\
Soil available phosphorus content & $\mathrm{g} / \mathrm{kg}$ & 3.52 & 0.39 & 9.30 \\
Socio-economic factors & & & & \\
Population density within a 1,000-m radius & $\mathrm{person} / \mathrm{ha}$ & 91.7 & 2.23 & 319 \\
Road density within a 1,000-m radius & $\mathrm{m} / \mathrm{ha}$ & 49.6 & 8.58 & 125 \\
Road area ratio within a 1,000-m radius & $\%$ & 5.47 & 0.55 & 17.4 \\
Residential land area ratio within a 1,000-m radius & $\%$ & 11.4 & 0.96 & 38.3 \\
Industrial land area ratio within a 1,000-m radius & $\%$ & 5.06 & 0.00 & 13.4 \\
\hline
\end{tabular}

*The relationships between these factors and the invasive/naturalized ratios of 19 major urban forests of Shenzhen were examined (unless otherwise stated).

\section{Information on the environmental and socio-economic factors of 19 major urban forests of Shenzhen}

Beyond the soil physico-chemical properties mentioned above, information on six additional environmental factors of the 19 major urban forests were collected (Tables 1 and S2): area, average altitude, mean January temperature, mean July temperature, annual average precipitation, and the density of native plant species (i.e., the number of native plant species per hectare). These factors were selected because they are generally expected to have a marked influence on the richness of exotic plants (Wu et al., 2006; Zhang et al., 2004; Cutway and Ehrenfeld, 2009; Peacock et al., 2006). The data on mean January temperature, mean July temperature, and annual average precipitation were means for the period from 2007 to 2012, which were provided by the Meteorological Bureau of Shenzhen Municipality.

Data on the following five socio-economic factors were obtained from the Development Research Center of the Urban Planning, Land and Resources Commission of Shenzhen Municipality (Tables 1 and S3): population density, road density, road area ratio, residential land area ratio and industrial land area ratio. These values were calculated for a buffer zone within a radius of 1,000 $\mathrm{m}$ from the edge of individual urban forests under study. These factors were selected because they are suitable indicators of disturbance resulting from socio-economic development and often have strong associations with exotic plant invasions (Pauchard and Alaback, 2004; Christen and Matlack, 2006; Pyšek et al., 2010; Santos et al., 2011). GDP was not included 
because the GDPs in the different districts of Shenzhen in the past five years were highly correlated with district population $(\mathrm{R}>0.667, \mathrm{P}<0.01)$. The distance of $1,000 \mathrm{~m}$ to the edge of individual forests was selected because the propagule pressure of exotic plant species tends to be strongest within a few hundred meters of the source and declines rapidly with increasing distance (Vilà and Pujadas, 2011).

\section{Statistical analysis}

Tracking and characterizing the naturalization-to-invasion transition of many exotic plant species in a given area (e.g., a city) appears to be impractical, if not impossible. Therefore, we tried to circumvent this perceived difficulty by calculating the ratio of the number of invasive exotic plant species belonging to a given subset to the number of naturalized exotic plant species belonging to the subset (hereafter referred to as 'invasive/naturalized') and using it as a surrogate measure of the probability that the naturalized exotic plant species belonging to the subset will succeed in the naturalization-invasion transition. To assess the effects of plant attributes on the transition from naturalization to invasion of the exotic plants in Shenzhen, we calculated invasive/naturalized for subsets of the exotic plant species in Shenzhen with respect to their taxonomic group, geographic origin and life form. To explore the effects of environmental and socio-economic factors on the transition, we calculated invasive/naturalized for each of the 19 major urban forests under study and tested the correlations between these ratios and the environmental and socio-economic factors of the forests and their surroundings, respectively, using linear regression analysis. Note however that Tiantou Mountain was excluded in the analysis of relationships between these ratios and environmental factors, because the soil moisture and organic matter content of the forest deviated from the normal ranges (Table S2). All of the statistical analyses were performed using the statistical software package SPSS (Statistical Package for the Social Sciences) for Windows Version 17.0 (SPSS Inc., Chicago, IL, USA).

\section{Results}

\section{An overview of naturalized and invasive exotic plant species in Shenzhen}

We found 349 naturalized plant species in Shenzhen, including 343 angiosperm species, 5 pteridophyte species and 1 gymnosperm species (Table S4). They belong to 241 genera and 75 families, accounting for approximately $12.2 \%$ of the total number of plant species in Shenzhen. A total of 117 invasive plant species were identified in Shenzhen (Table S5), indicating that $33.5 \%$ of the exotic plants naturalized in Shenzhen have become invasive. The invasive plants were all angiosperms, belonging to 88 genera and 33 families (Table S5).

\section{The effects of plant attributes on the naturalization-to-invasion transition of exotic plant species in Shenzhen}

The invasive plant species in Shenzhen were highly unevenly distributed across taxonomic groups, geographic origins and life forms. The five families that contained the most invasive plant species were Asteraceae (also called Compositae), Fabaceae (Leguminosae), Poaceae (Gramineae), Amaranthaceae and Solanaceae (Fig. 2). Specifically, there were $35,13,7,7$ and 7 invasive species in these families, 
respectively (Fig. 2a), which accounted for 62.5\%, 32.5\%, 26.9\%, 43.8\% and $43.8 \%$ of the total number of naturalized exotic species in the corresponding families (Fig. $2 b$ ). The genera having the most invasive plant species were Amaranthus and Ipomoea, followed by Senna, Solanum and Euphorbia (Fig. 3). There were 5, 5, 3, 3 and 2 invasive species in each of these genera, respectively (Fig. 3a), which accounted for $83.3 \%, 45.4 \%, 42.9 \%, 33.3 \%$ and $60.0 \%$ of the total number of naturalized species in the corresponding genera (Fig. 3b). As for geographical origin, the majority of the invasive plants were native to the Americas, followed by Asia, Africa, Europe, the Mediterranean and Oceania (Fig. 4a). These areas contributed 90, 8, 8, 6, 2 and 2 invasive species, respectively (Fig. 4a), which accounted for 47.4\%, 12.7\%, 30.8\%, $26.1 \%, 25.0 \%$ and $40.0 \%$ of the total number of naturalized species that had originated from the corresponding areas (Fig. 4b). Regarding life form, the invasive plants were mainly herbs (Fig. 5a). Specifically, more than 96 invasive plant species were herbs, accounting for $35.0 \%$ of the total number of herbaceous naturalized plant species in Shenzhen (Fig. 5b).
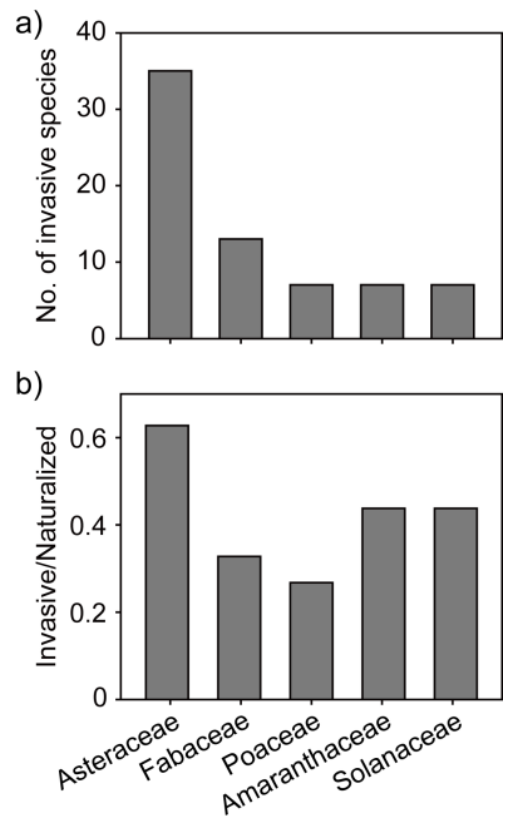

Figure 2. The most successful families of exotic plant species in Shenzhen. The five families containing the most invasive plant species (a) and the ratios of invasive to naturalized species in these families $(b)$.

The effects of environmental and socio-economic factors on the naturalization-to-invasion transition of exotic plants in 19 major urban forests of Shenzhen

In the field surveys, we identified 316 naturalized plant species and 111 invasive plant species in the 19 major urban forests, which accounted for $90.5 \%$ and $94.9 \%$ of the total number of naturalized and invasive plant species in Shenzhen, respectively. The number of invasive plant species recorded in urban forests ranged from 19 to 69. In contrast, invasive/naturalized for these urban forests exhibited considerably less variation, ranging from 0.35 to 0.49 . However, invasive/naturalized was significantly ( $P$ $<0.05$ ) correlated with four environmental factors considered (Fig. 6). Specifically, the 
density of native plant species and soil density were negatively correlated with invasive/naturalized (Figs. $6 a$ and $b$ ), whereas soil moisture and soil organic matter were positively correlated with invasive/naturalized (Figs. $6 c$ and $d$ ). There was no significant relationship between any of the five socio-economic factors and invasive/naturalized.
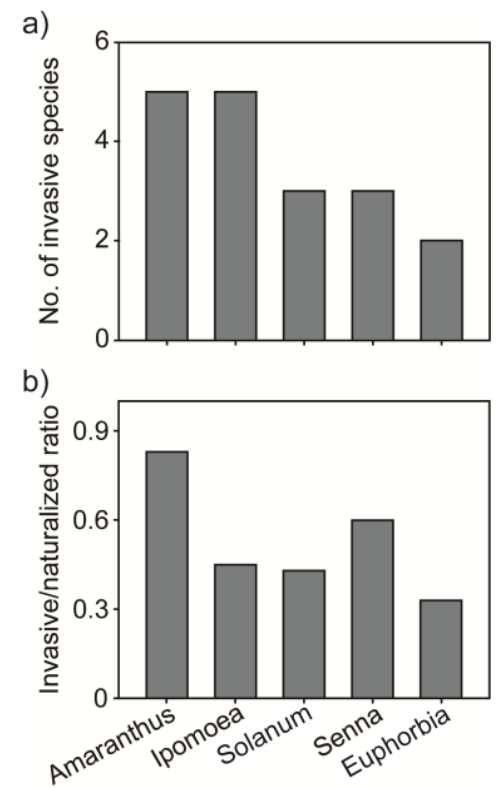

Figure 3. The most successful genera of exotic plant species in Shenzhen. The five genera containing the most invasive plant species (a) and the ratios of invasive to naturalized species in these genera $(b)$.

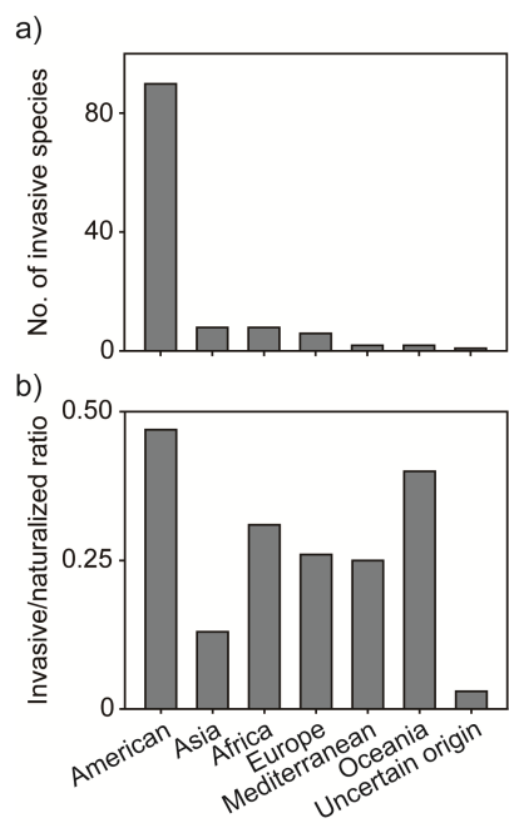

Figure 4. Effects of geographic origin on the success of exotic plant species in Shenzhen. Effects of geographic origin on the number of invasive species (a) and the naturalization-to-invasion transition of exotic plant species (b) in Shenzhen. 
a)

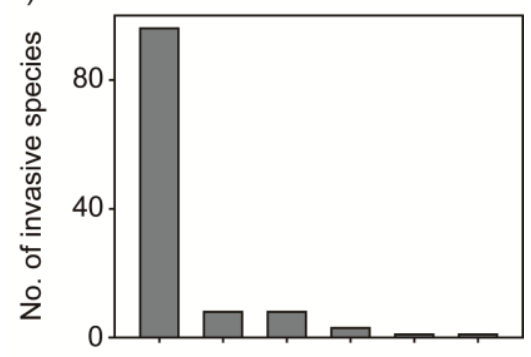

b)

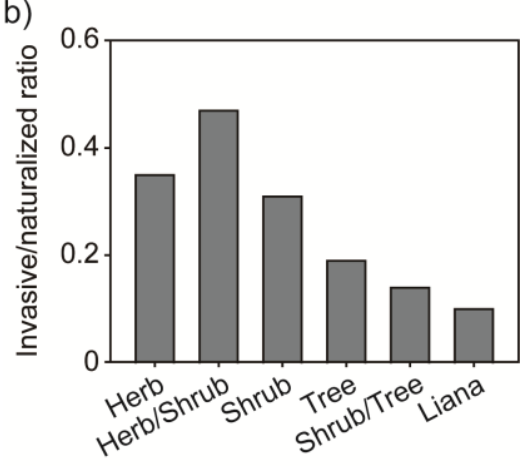

Figure 5. Effects of life form on the success of exotic plant species in Shenzhen. Effects of life form on the number of invasive species (a) and the naturalization-to-invasion transition of exotic plant species in Shenzhen (b).
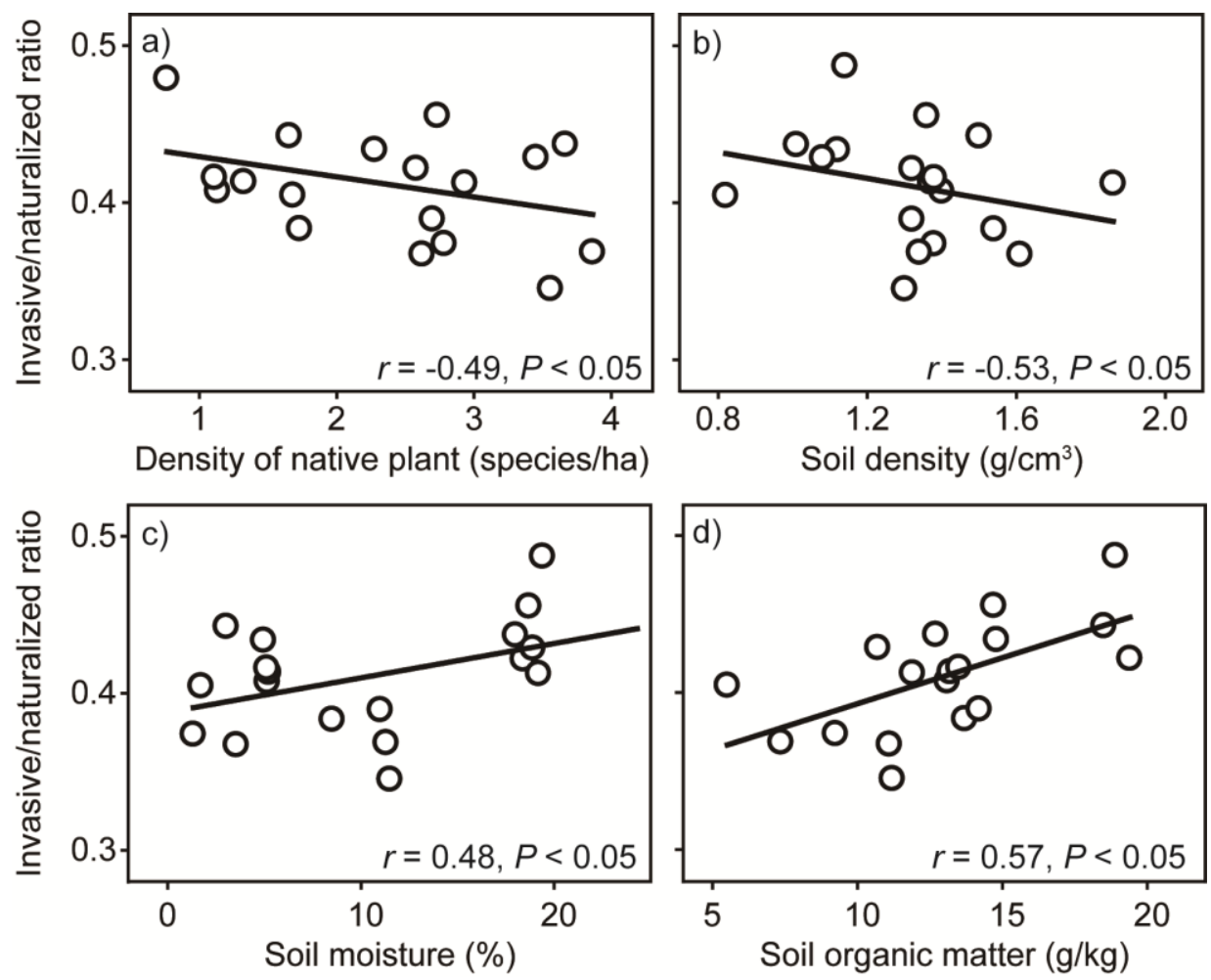

Figure 6. Effects of environmental factors on the success of exotic plant species in Shenzhen. Effects of density of native plants $(a)$, soil density $(b)$, soil moisture $(c)$ and soil organic matter $(d)$ on the naturalization-to-invasion transition of exotic plant species in 18 major urban forests in

Shenzhen. Each data point represents one forest. 


\section{Discussion}

In this study, 349 naturalized plant species were found in Shenzhen, representing $40.5 \%$ of all 861 naturalized plant species in China (Jiang et al., 2011). Moreover, the number of naturalized plant species in Shenzhen was considerably higher than that (112) in Beijing, another rapidly urbanizing city in China (Wang et al., 2011). The presence of this high number of naturalized plant species in Shenzhen made it a suitable city for studying the naturalization-to-invasion transition of exotic plant species in rapidly urbanizing areas. Indeed, $43.3 \%$ of all 270 invasive plant species in China (Weber et al., 2008) were present in Shenzhen.

As expected, the invasive/naturalized ratios recorded in this study far exceeded 0.1. This finding cannot be considered novel, given that Williamson and Fitter (Williamson and Fitter, 1996) had long noted that approximately $20 \%$ of exotic crop plant species naturalized in Canada became invasive. However, the naturalization-to-invasion transition of exotic plants in urban forests of rapidly urbanizing cities deserves more explicit attention. The invasive/naturalized ratios for urban forests (ranging from 0.35 to 0.49) observed in this study were comparable to those (with an average of 0.43 ) obtained in urban roadsides, parks and gardens in Beijing (Wang et al., 2011), possibly indicating that urban forests are not necessarily more resistant to exotic plant invasion than other urban habitats. Here, we have attempted to elucidate the reasons for these extreme invasive/naturalized values by investigating the effects of plant attributes and environmental and socio-economic factors on the naturalization-to-invasion transition of exotic plants in Shenzhen, although further studies are needed to test whether our finding is applicable to other rapidly urbanizing cities around the world.

The effects of plant attributes on the naturalization-to-invasion transition of exotic plant species in Shenzhen were mirrored not only by the highly uneven distribution of invasive species across taxonomic groups, geographic origins and life forms but also by the associated invasive/naturalized ratios. First, the Asteraceae family contained the highest number of invasive plant species (34), which accounted for $29.1 \%$ of all invasive plant species in Shenzhen and $12.6 \%$ of all invasive plant species in China (Weber et al., 2008). Moreover, invasive/naturalized in this family was 0.61 , possibly suggesting that the naturalized members of this family are highly successful in the naturalization-to-invasion transition. Similarly, the Asteraceae family accounted for $31.3 \%$ of the total number of invasive plant species in Beijing, associated with an invasive/naturalized value of 0.75 (Wang et al., 2011). This performance may be partially attributed to the plant traits that contribute to the strong dispersal and establishment abilities of this family, such as a large number of small and light seeds, rapid germination and a high germination rate (Pyšek, 1997). At the genus level, Amaranthus was found to contain the highest number of invasive species (5) and show a high invasive/naturalized value of 0.83 , which corresponds with the fact that many species in this genus have been reported as invasive species in other parts of the world and tend to germinate quickly, grow rapidly and produce more leaf area (Horak and Loughin, 2000; Steckel, 2007; Steckel et al., 2004). Second, 76.9\% of the invasive species found in Shenzhen originated from the Americas, a higher percentage than that (70.8\%) of Beijing (Wang et al., 2011). However, the percentages for these two Chinese cities were greater than that (68\%) reported for China as a whole (Liu et al., 2006). Moreover, the invasive/naturalized ratio (0.47) for American plants was higher than those for other geographic origins. In fact, Wang et al. reported similar patterns in Beijing (Wang et al., 2011). Similar environmental conditions and the high volume of 
commerce between the invaded and native ranges were considered as possible explanations for the numerical predominance of American invasive plants and their high invasive/naturalized ratios, following the suggestions of previous work (Liu et al., 2006). Our subsequent analyses showed that the former was more likely to be a major reason (see the next paragraph for more details). Third, herbaceous species accounted for $82.1 \%$ of the total invasive species in Shenzhen, which exhibited an invasive/naturalized value (0.35) greater than expected from the Tens Rule (Williamson and Fitter, 1996). A similar pattern was observed in Beijing (Wang et al., 2011). Additionally, approximately $88 \%$ of all of the invasive plant species in China were herbaceous (Liu et al., 2006). These findings may be partially explained by the fact that many herbaceous invasive species are characterized by their rapid growth and reproduction (Sakai et al., 2001), which may facilitate the rapid evolutionary adaptation of these invasive plants to novel environments (Prentis et al., 2008).

We assessed the effects of environmental and socio-economic factors on the naturalization-to-invasion transition of exotic plants in urban forests of Shenzhen by identifying significant relationships between the selected factors and the invasive/naturalized ratios (Weber et al., 2008; Liu et al., 2006). The negative relationship between the density of native plant species and the invasive/naturalized ratio may indicate that native biodiversity represses the transition, which would be consistent with the widely accepted notion that biodiversity is a barrier to ecological invasion (Kennedy et al., 2002). Although there is currently no report addressing the effects of soil density on plant invasion, the negative relationship between soil density and invasive/naturalized may be attributed to the inhibitory effects of elevated soil density on the germination, growth and reproduction of plants (Ehrenfeld et al., 2005). In contrast, soil moisture and organic matter content were positively correlated with the invasive/naturalized ratio, likely indicating that wetter and richer soils tended to be beneficial to the transition. In agreement with these results, previous studies have shown that wetter and richer soils were associated with higher germination and survival rate of invasive plants, as well as a greater number of invader seeds (Ehrenfeld et al., 2001; Warren et al., 2013). The lack of significant associations between the socio-economic factors and the invasive/naturalized ratio was initially surprising. This unexpected finding, in combination with other results of the present study, instead suggests that although human activities facilitate the initial establishment of exotic plants, biotic and environmental factors are more likely to be the major drivers of their further spread and impacts (Stohlgren et al., 2005). However, the effects of human activities on plant invasion may vary greatly at different spatial scales. Indeed, there is evidence that socio-economic factors could promote plant invasion at a provincial scale in China (Lin et al., 2007; Liu et al., 2005).

There are a few potential caveats with this study. First, the invasive/naturalized ratio may be a good measure to assess the overall success of the naturalization-invasion transition of exotic plants in a given area, but it does not represent the long-term ecological processes associated with the transition. Second, as noted by Vilà and Pujadas (Vilà and Pujadas, 2011), correlations between variables do not necessarily imply causation. Third, some variables not under consideration in this study could have an effect on the transition (Phillips et al., 2010; Milbau and Stout, 2008). However, despite these caveats, this study provided new insights into the factors driving the naturalization-to-invasion transition of exotic plants in a rapidly urbanizing area, particularly for urban forests. Nonetheless, 
if the findings of this study prove to be applicable to other rapidly urbanizing areas, they will be useful in developing a more objective and accurate approach for managing and predicting plant invasions in these areas.

Acknowledgments. We thank Prof. Wen-bo Liao for his constructive comments, which helped us to improve the manuscript. We also want to express our appreciation to many unnamed managers and staff at the Shenzhen Urban Planning and Land Resource Research Center, the Meteorological Service Center of Shenzhen Meteorological Bureau, and the Shenzhen Geotechnical Investigation and Surveying Institute for their help in gathering the related data.

\section{REFERENCES}

[1] Celesti-Grapow, L., Pyšek, P., Jarošík, V. and Blasi, C. (2006): Determinants of native and alien species richness in the urban flora of Rome. - Diversity and Distribution 12: 490-501.

[2] Chen, W.Y. and Wang, D.T. (2013): Urban forest development in China: natural endowment or socioeconomic product? - Cities 35: 62-68.

[3] Christen, D. and Matlack, G. (2006): The role of roadsides in plant invasions: a demographic approach. - Conservation Biology 20: 385-391.

[4] Cutway, H.B. and Ehrenfeld, J.G. (2009): Exotic plant invasions in forested wetlands: effects of adjacent urban land use type. - Urban Ecosystems 12: 371-390.

[5] Dobbs, C., Francisco, J.E. and Wayne, C.Z. (2011) A framework for developing urban forest ecosystem services and goods indicators. - Landscape and Urban Planning 99: 196-206.

[6] Dolan, R.W., Moore, M.E. and Stephens, J.D. (2011): Documenting effects of urbanization on flora using herbarium records. - Journal of Ecology 99(4): 1055-1062.

[7] Ehrenfeld, J.G., Kourtev, P. and Huang W. (2001): Changes in soil functions following invasions of exotic understory plants in deciduous forests. - Ecological Applications 11(5): 1287-1300.

[8] Ehrenfeld, J.G., Ravit, B. and Elgersma, K. (2005): Feedback in the plant-soil system. Annual Review of Environment and Resources 30(1): 75-115.

[9] Escobedo, F.J., Kroeger, T. and Wagner, J.E. (2011): Urban forests and pollution mitigation: analyzing ecosystem services and disservices. - Environmental Pollution 159: 2078-2087.

[10] Feng, J. and Zhu, Y. (2010): Alien invasive plants in China: risk assessment and spatial patterns. - Biodiversity and Conservation 19(12): 3489-3497.

[11] Flora of China. 2013: Available: http://foc.eflora.cn/ (accessed on $30^{\text {th }}$ June 2016)

[12] Horak, M.J. and Loughin, T.M. (2000): Growth analysis of four Amaranthus species. Weed Science 48(3): 347-355.

[13] Jiang, H., Fan, Q., Li, J.T., Shi, S., Li, S.P., Liao, W.B. and Shu, W.S. (2011): Naturalization of alien plants in China. - Biodiversity and Conservation 20(7): 1545-1556.

[14] Kennedy, T.A., Naeem, S., Howe, K.M., Knops, J.M., Tilman, D. and Reich, P. (2002): Biodiversity as a barrier to ecological invasion. - Nature 417(6889): 636-638.

[15] Kolar, C.S. and Lodge, D.M. (2001). Progress in invasion biology: predicting invaders. Trends in Ecology \& Evolution 16(4): 199-204.

[16] Leung, G.P.C., Hau, B.C.H. and Corlett, R.T. (2009): Exotic plant invasion in the highly degraded upland landscape of Hong Kong, China. - Biodiversity and Conservation 18: 191-202.

[17] Li, P.Q., Li, Y. (2010): Flora of Shenzhen. Chinese Forestry Publishing House, Beijing, China. 
[18] Lin, W., Zhou, G.F., Cheng, X.Y. and Xu, R.M. (2007): Fast economic development accelerates biological invasions in China. - PLoS One 2(11):e1208.

[19] Liu, J., Dong, M., Miao, S.L., Li, Z.Y., Song, M.H. and Wang, R.Q. (2006): Invasive alien plants in China: role of clonality and geographical origin. - Biological Invasions 8: 1461-1470.

[20] Liu, J., Liang, S.C., Liu, F.H., Wang, R.Q. and Dong, M. (2005): Invasive alien plant species in China: regional distribution patterns. - Diversity and Distributions 11: 341-347.

[21] Liu, X.Z., Heilig, G.K., Chen, J.M. and Heino, M. (2007): Interactions between economic growth and environmental quality in Shenzhen, China's first special economic zone. Ecological Economics 62(3-4): 559-570.

[22] Lososová, Z., Chytrý, M., Tichý, L., Danihelka, J., Fajmon, K. and Hájek, O. (2012): Native and alien floras in urban habitats: a comparison across 32 cities of central Europe. - Global Ecology and Biogeography 21(5): 545-555.

[23] McKinney, M.L. (2002): Influence of settlement time, human population, park shape and age, visitation and roads on the number of alien plant species in protected areas in the USA. - Diversity Distribution 8: 311-318.

[24] McKinsey Global Institute (MGI). (2012): Urban world: cities and the rise of the consuming class. Available: http://www.mckinsey.com/global-themes/urbanization/urbanworld-cities-and-the-rise-of-the-consuming-class (accessed on $30^{\text {th }}$ June 2016).

[25] McNeely, J.A., Mooney, H.A., Neville, L.E., Schei, P. and Waage, J.K. (2001): A Global strategy on invasive alien species. Gland, Switzerland: IUCN.

[26] Milbau, A. and Stout, J.C. (2008): Factors associated with alien plants transitioning from casual, to naturalized, to invasive. - Conservation Biology 22(2): 308-317.

[27] Nowak, D.J., Stein, S.M., Randler, P.B., Greenfield, E.J., Comas, S.J., Carr, M.A. and Alig, R.J. (2010): Sustaining America's urban trees and forests. - General technical report NRS- 62. Newton Square, PA: USDA Forest Service, Northern Research Station.

[28] Pauchard, A., Aguayo, M., Peña, E. and Urrutia, R. (2006): Multiple effects of urbanization on the biodiversity of developing countries: the case of a fast-growing metropolitan area (Concepción, Chile). - Biological Conservation 127(3): 272-281.

[29] Pauchard. A. and Alaback, P.B. (2004): Influence of elevation, land use, and landscape context on patterns of alien plant invasions along roadsides in protected areas of south-central Chile. - Conservation Biology 18(1): 238-248.

[30] Peacock, L., Worner, S.P. and Sedcole, R. (2006): Climate variables and their role in site discrimination of invasive insect species distributions. - Environmental Entomology 35(4): 958-963.

[31] Perrings, C., Williamson, M., Barbier, E.B., Delfino, D., Dalmazzone, S., Shogren, J., Simmons, P. and Watkinson, A. (2002): Biological invasion risks and the public good: an economic perspective. - Conservation Ecology 6(1): 1.

[32] Phillips, M.L., Murray, B.R., Leishman, M.R. and Ingram, R. (2010): The naturalization to invasion transition: are there introduction-history correlates of invasiveness in exotic plants of Australia? - Australian Ecology 35(6): 695-703.

[33] Pimentel, D., Zuniga, R. and Morrison, D. (2005): Update on the environmental and economic costs associated with alien-invasive species in the United States. - Ecological Economy 52(3): 273-288.

[34] Prentis, P.J., Wilson, J.R.U., Dormontt, E.E., Richardson, D.M. and Lowe, A.J. (2008): Adaptive evolution in invasive species. - Trends in Plant Science 13(6): 288-294.

[35] Pyšek, P. (1997): Compositae as invaders - better than the others? - Preslia. 69: 9-22.

[36] Pyšek, P. (1998): Alien and native species in Central European urban floras: a quantitative comparison. - Journal of Biogeography 25(1): 155-163.

[37] Pyšek, P., Jarošík, V., Hulme, P.E., Kühn, I., Wild, J., Arianoutsou, M., Bacher, S., Chiron, F., Didziulis, V., Essl, F., Genovesi, P., Gherardi, F., Hejda, M., Kark, S., Lambdon, P.W., Desprez-Loustau, M.L., Nentwig, W., Pergl, J., Poboljsaj, K., Rabitsch. W., Roques, A., Roy, D.B., Shirley, S., Solarz, W., Vilà, M. and Winter, M. (2010): 
Disentangling the role of environmental and human pressures on biological invasions across Europe. - Proceedings of the National Academy of Sciences of the United States of America 107(27): 12157-12162.

[38] Richardson, D.M. and Pyšek, P. (2006): Plant invasions: merging the concepts of species invasiveness and community invisibility. - Progress in Physical Geography 30: 409-431.

[39] Richardson, D.M., Pyšek, P., Rejmánek, M., Barbour, M.G., Panetta, D.F. and West, C.J. (2000): Naturalization and invasion of alien plants: concepts and definitions. - Diversity and Distributions 6(2):93-107.

[40] Ricotta, C., Godefroid, S. and Rocchini, D. (2010): Invasiveness of alien plants in Brussels is related to their phylogenetic similarity to native species. - Diversity and Distribution 16: 655-662.

[41] Ricotta, C., La, Sorte, F.A., Pyšek, P., Rapson, G.L., Celesti-Grapow, L. and Thompson, K. (2009). Phyloecology of urban alien floras. - Journal of Ecology 97(6): 1243-1251.

[42] Romanuk, T.N., Zhou, Y., Brose, U., Berlow, E.L., Williams, R.J. and Martinez, N.D. (2009): Predicting invasion success in complex ecological networks. - Philosophical Transaction of the Royal Society B: Biological Sciences 364(1524): 1743-1754.

[43] Sakai, A.K., Allendorf, F.W., Holt, J.S., Lodge, D.M., Molofsky, J., With, K.A., Baughman, S., Cabin, R.J., Cohen, J.E., Ellstrand, N.C., McCauley, D.E. , O'Neil, P., Parker, I.M. , Thompson, J.N. and Weller, S.G. (2001): The population biology of invasive species. - Annual Review of Ecology and Systematics 32(1): 305-332.

[44] Santos, M., Freitas, R., Crespí, A.L., Hughes, S.J. and Cabral, J.A. (2011): Predicting trends of invasive plants richness using local socio-economic data: an application in North Portugal. - Environmental Research 111(7): 960-966.

[45] Schinner, F., Öhlinger, R., Kandeler, E. and Margesin, R. (1996): Methods in soil biology. - Springer, Berlin, Germany.

[46] Shao, Z.F., Zhao, H.B., Qiu, S.S., Yang, Y.B., Peng, S.L., Lu, C.F.and Chen, Z.Q. (2006): Study on the most harmful exotic plant in Shenzhen city. - Ecological Environment 15(3): 587-593.

[47] Shenzhen Entry-Exit Inspection and Quarantine Bureau (SEEIQB). (2010): An annual report of SEEIQB in 2010. - SEEIQB, Shenzhen, China.

[48] Singh, K.K., Davis, A.J. and Meentemeyer, R.K. (2015): Detecting understory plant invasion in urban forests using LiDAR. - International Journal of Applied Earth Observation of Geoinformation 38: 267-279.

[49] Spear, D., Foxcroft, L.C., Bezuidenhout, H. and McGeoch, M.A. (2013): Human population density explains alien species richness in protected areas. - Biological Conservation 159: 137-147.

[50] Statistics Bureau of Shenzhen Municipality (SBSM). (2013): Shenzhen Statistics Yearbook 2013. - SBSM, Shenzhen, China.

[51] Stecke, L.E., Sprague, C.L., Stoller, E.W. and Wax, L.M. (2004): Temperature effects on germination of nine Amaranthus species. - Weed Science 52: 217-221.

[52] Steckel, L.E. (2007): The dioecious Amaranthus spp.: here to stay. - Weed Technology 21: 567-570.

[53] Stohlgren, T.J., Barnett, D., Flather, C., Kartesz, J. and Peterjohn, B. (2005): Plant species invasions along the latitudinal gradient in the United States. - Ecology 86(9): 2298-2309.

[54] United Nations Population Division (UNPD). (2006): World population prospects: the 2005 revision. - UN, New York, U.S.A.

[55] United Nations Population Division (UNPD). (2016): World urbanization prospects: the 2015 revision. - UNPD, New York; U.S.A.

[56] Vilà, M. and Pujadas, J. (2011): Land-use and socio-economic correlates of plant invasions in European and North African countries. - Biological Conservation 100: 397-401.

[57] Vilà, M., Basnou, C., Pyšek, P., Josefsson, M., Genovesi, P., Gollasch, S., Nentwig, W., Olenin, S., Roques, A., Roy, D., Hulme, P.E., and DAISIE partners (2010): How well do 
we understand the impacts of alien species on ecosystem services? A pan-european, cross-taxa assessment. - Frontiers in Ecology and the Environment 8(3): 135-144.

[58] Vilà, M., Espinar, J.L., Hejda, M., Hulme, P.E., Jarošík, V., Maron, J.L., Jan Pergl, J., Schaffner, U., Sun, Y. and Pyšek, P. (2011): Ecological impacts of invasive alien plants: a meta-analysis of their effects on species, communities and ecosystems. - Ecology Letters 14(7): 702-708.

[59] Vitousek, P.M., D’Antonio, C.M., Loope, L.L., Rejmánek, M. and Westbrooks, R. (1997): Introduced species: a significant component of human-based global change. - New Zealand Journal of Ecology 21(1): 1-16.

[60] Wan, F.H., Liu, Q.R., Xie, M. (2012): Biological invasions: color illustrations of invasive alien plants in China. - Science Press, Beijing, China.

[61] Wang, H.F., López-Pujol, J., Meyerson, L.A., Qiu, J.X., Wang, X.K., Ouyang, Z.Y. (2011): Biological invasions in rapidly urbanizing areas: a case study of Beijing, China. Biodiversity and Conservation 20(11): 2483-2509.

[62] Warren II, R.J., Bahn, V., Bradford, M.A. (2013): Decoupling litter barrier and soil moisture influences on the establishment of an invasive grass. - Plant and Soil 367(1): 339-346.

[63] Weber, E, Sun, S.G., Li, B. (2008): Invasive alien plants in China: diversity and ecological insights. - Biological Invasions 10(8): 1411-1429.

[64] Williamson, M.H., Fitter, A. (1996): The varying success of invaders. - Ecology 77(6): 1661-1666.

[65] Wu, X.W., Luo, J., Chen, J.K., Li, B. (2006): Spatial patterns of invasive alien plants in China and its relationship with environmental and anthropological factors. - Journal of Plant Ecology 30(4): 576-584.

[66] Xu, H., Ding, H., Li, M., Qiang, S., Guo, J., Han, Z., Huang, Z., Sun, H., He, S., Wu, H., Wan, F. (2006): The distribution and economic losses of alien species invasion to China. Biological Invasion 8(7): 1495-1500.

[67] Xu, H.G., Qiang S. (2011): China's invasive alien species. - Science Press, Beijing, China.

[68] Yan, Y.H., Xing, F.W., Huang, X.X., Fu, Q., Qin, X.S. and Chen, H.F. (2004): Exotic plants in Shenzhen, China. - Guihaia 24(3): 232-238.

[69] Zhang, L.Y., Ye, W.H., Cao, H.L., Feng, H.L. (2004): Mikania micrantha H.B.K in China - an overview. - Weed Research 44: 42-49. 


\section{APPENDIX}

Table S1. Environmental factors of 19 major urban forests of Shenzhen*

\begin{tabular}{|c|c|c|c|c|c|c|c|}
\hline Code & Forest ecosystem & Area (ha) & $\begin{array}{l}\text { Average altitude } \\
\text { (m) }\end{array}$ & $\begin{array}{c}\text { Mean January } \\
\text { temperature } \\
\left({ }^{\circ} \mathrm{C}\right) \\
\end{array}$ & $\begin{array}{c}\text { Mean July } \\
\text { temperature }\left({ }^{\circ} \mathrm{C}\right)\end{array}$ & $\begin{array}{c}\text { Annual average } \\
\text { precipitation }(\mathrm{mm})\end{array}$ & $\begin{array}{c}\text { Density of native } \\
\text { plant species } \\
\text { (species/ha) }\end{array}$ \\
\hline 1 & Nanshan & 351 & 143 & 14.2 & 28.3 & 1311 & 1.70 \\
\hline 2 & Fenghuang Mountain & 243 & 126 & 13.6 & 28.7 & 1799 & 2.57 \\
\hline 3 & Tiegang & 5401 & 68.0 & 13.7 & 28.6 & 1705 & 1.62 \\
\hline 4 & Yangtai Mountain & 2843 & 219 & 13.8 & 28.1 & 1574 & 2.23 \\
\hline 5 & Guangming & 2063 & 129 & 13.7 & 29.1 & 1565 & 1.12 \\
\hline 6 & Guanlan & 2211 & 120 & 14.1 & 29.5 & 1606 & 1.30 \\
\hline 7 & Wuzhipa & 485 & 112 & 14.4 & 29.5 & 1485 & 1.65 \\
\hline 8 & Meilin & 118 & 82.0 & 13.9 & 28.7 & 1572 & 2.72 \\
\hline 9 & Lianhua Mountain & 180 & 57.4 & 14.4 & 28.5 & 1901 & 3.78 \\
\hline 10 & Bijia Mountain & 142 & 86.0 & 14.4 & 28.6 & 1653 & 3.48 \\
\hline 11 & Weiling & 87.2 & 107 & 13.8 & 28.7 & 1807 & 2.52 \\
\hline 12 & Buxin Mountain & 348 & 119 & 14.0 & 28.9 & 1772 & 0.76 \\
\hline 13 & Wutong Mountain & 2890 & 294 & 9.80 & 23.9 & 1548 & 3.58 \\
\hline 14 & Sanzhoutian & 3483 & 326 & 12.3 & 26.3 & 1387 & 2.67 \\
\hline 15 & Songzikeng & 1804 & 83.0 & 13.5 & 29.0 & 1583 & 1.09 \\
\hline 16 & Maluan Mountain & 3172 & 218 & 13.5 & 28.8 & 1509 & 2.64 \\
\hline 17 & Tiantou Mountain & 3003 & 229 & 13.2 & 29.2 & 1360 & 3.66 \\
\hline 18 & Dapeng Peninsula & 14500 & 208 & 14.2 & 28.8 & 1882 & 3.37 \\
\hline 19 & Qiniang Mountain & 4642 & 297 & 14.3 & 28.2 & 1705 & 2.87 \\
\hline
\end{tabular}

* Excluding soil physico-chemical properties. 
Table S2. Soil physico-chemical properties of 19 major urban forests of Shenzhen. Data are presented as means $(n=20-95)$.

\begin{tabular}{|c|c|c|c|c|c|c|c|c|}
\hline Code & Forest ecosystem & Density $\left(\mathrm{g} / \mathrm{cm}^{3}\right)$ & Porosity (\%) & Moisture (\%) & $\mathrm{pH}$ & $\mathrm{OM}^{*}(\mathrm{~g} / \mathrm{kg})$ & $\mathrm{TN}^{*}(\mathrm{~g} / \mathrm{kg})$ & $\mathrm{AP}^{*}(\mathrm{mg} / \mathrm{kg})$ \\
\hline 1 & Nanshan & 1.54 & 47.3 & 8.51 & 4.95 & 13.7 & 0.57 & 3.11 \\
\hline 2 & Fenghuang Mountain & 1.61 & 40.0 & 3.55 & 6.39 & 11.1 & 0.72 & 1.53 \\
\hline 3 & Tiegang & 1.50 & 44.6 & 3.03 & 4.55 & 18.5 & 0.71 & 2.51 \\
\hline 4 & Yangtai Mountain & 1.12 & 45.0 & 4.96 & 5.20 & 14.8 & 0.20 & 2.40 \\
\hline 5 & Guangming & 1.40 & 48.6 & 5.15 & 5.10 & 13.1 & 0.78 & 9.30 \\
\hline 6 & Guanlan & 1.37 & 47.9 & 5.23 & 5.51 & 13.2 & 0.90 & 4.60 \\
\hline 7 & Wuzhipa & 0.82 & 46.6 & 1.72 & 4.14 & 5.51 & 0.47 & 0.39 \\
\hline 8 & Meilin & 1.38 & 48.0 & 1.32 & 5.25 & 9.24 & 0.27 & 6.83 \\
\hline 9 & Lianhua Mountain & 1.34 & 51.4 & 11.3 & 5.56 & 7.36 & 0.15 & 4.48 \\
\hline 10 & Bijia Mountain & 1.30 & 45.4 & 11.5 & 5.40 & 11.2 & 1.01 & 2.32 \\
\hline 11 & Weiling & 1.32 & 55.4 & 18.4 & 5.02 & 19.4 & 0.54 & 0.92 \\
\hline 12 & Buxin Mountain & 1.14 & 52.4 & 19.4 & 5.27 & 18.9 & 0.44 & 0.80 \\
\hline 13 & Wutong Mountain & 1.01 & 55.3 & 18.0 & 5.15 & 12.7 & 0.30 & 7.80 \\
\hline 14 & Sanzhoutian & 1.36 & 50.6 & 18.7 & 4.56 & 14.7 & 0.72 & 1.41 \\
\hline 15 & Songzikeng & 1.38 & 47.2 & 5.13 & 5.03 & 13.5 & 0.55 & 1.07 \\
\hline 16 & Maluan Mountain & 1.32 & 58.7 & 11.0 & 4.77 & 14.2 & 0.52 & 2.24 \\
\hline 17 & Tiantou Mountain & 1.20 & 54.6 & 24.3 & 4.23 & 38.0 & 1.59 & 4.81 \\
\hline 18 & Dapeng Peninsula & 1.08 & 34.2 & 18.9 & 4.64 & 10.7 & 0.67 & 3.95 \\
\hline 19 & Qiniang Mountain & 1.86 & 42.5 & 19.2 & 5.30 & 11.9 & 1.11 & 6.33 \\
\hline
\end{tabular}

*: OM, organic matter content; TN, total nitrogen content; AP, available phosphorus content. 
Table S3. Socio-economic factors of 19 major urban forests of Shenzhen.

\begin{tabular}{|c|c|c|c|c|c|c|}
\hline Code & Forest ecosystem & $\begin{array}{l}\text { Population density within } \\
\text { a } 1,000-\mathrm{m} \text { radius } \\
\text { (person/ha) }\end{array}$ & $\begin{array}{l}\text { Road density within } \\
\text { a } 1,000-\mathrm{m} \text { radius } \\
(\mathrm{m} / \mathrm{ha})\end{array}$ & $\begin{array}{l}\text { Road area ratio within } \\
\text { a } 1,000-\mathrm{m} \text { radius area } \\
\qquad \%)\end{array}$ & $\begin{array}{l}\text { Residential land area } \\
\text { ratio within a } \\
1,000 \text {-m radius }(\%)\end{array}$ & $\begin{array}{l}\text { Industrial land area ratio } \\
\text { within a } 1,000-\mathrm{m} \text { radius } \\
\qquad(\%)\end{array}$ \\
\hline 1 & Nanshan & 74.9 & 72.3 & 0.91 & 23.0 & 5.39 \\
\hline 2 & Fenghuang Mountain & 73.5 & 57.1 & 8.46 & 8.23 & 6.99 \\
\hline 3 & Tiegang & 107 & 44.8 & 6.43 & 5.53 & 6.57 \\
\hline 4 & Yangtai Mountain & 80.0 & 51.5 & 6.14 & 6.17 & 4.91 \\
\hline 5 & Guangming & 68.9 & 27.4 & 3.13 & 5.46 & 12.8 \\
\hline 6 & Guanlan & 28.2 & 20.8 & 2.22 & 2.85 & 4.92 \\
\hline 7 & Wuzhipa & 32.6 & 51.4 & 7.97 & 2.06 & 13.4 \\
\hline 8 & Meilin & 144 & 59.0 & 5.31 & 16.7 & 0.47 \\
\hline 9 & Lianhua Mountain & 221 & 125 & 17.4 & 32.6 & 6.29 \\
\hline 10 & Bijia Mountain & 272 & 101 & 12.0 & 25.4 & 6.53 \\
\hline 11 & Weiling & 319 & 79.5 & 7.40 & 38.3 & 3.53 \\
\hline 12 & Buxin Mountain & 154 & 52.7 & 5.03 & 21.4 & 3.77 \\
\hline 13 & Wutong Mountain & 59.2 & 43.5 & 5.43 & 7.42 & 1.09 \\
\hline 14 & Sanzhoutian & 17.3 & 25.6 & 2.61 & 2.99 & 2.25 \\
\hline 15 & Songzikeng & 30.3 & 59.2 & 7.00 & 8.06 & 8.40 \\
\hline 16 & Maluan Mountain & 15.3 & 23.8 & 2.16 & 3.65 & 2.93 \\
\hline 17 & Tiantou Mountain & 32.9 & 20.5 & 2.08 & 1.56 & 5.17 \\
\hline 18 & Dapeng Peninsula & 9.37 & 19.0 & 1.75 & 3.43 & 0.88 \\
\hline 19 & Qiniang Mountain & 2.23 & 8.58 & 0.55 & 0.96 & 0.00 \\
\hline
\end{tabular}


Table S4. Checklist of naturalized plant species in Shenzhen.

\begin{tabular}{|c|c|c|c|c|c|}
\hline Code & Species & Family & Genus & Geographic origin & Life form \\
\hline & & Acanthaceae & & & \\
\hline 1 & Adhatoda vasica & Acanthaceae & Adhatoda & America & Shrub \\
\hline 2 & Andrographis paniculata & Acanthaceae & Andrographis & South Asia, India, Australia & Herb \\
\hline 3 & Barleria cristata & Acanthaceae & Barleria & Asia & Shrub \\
\hline 4 & Ruellia brittonina & Acanthaceae & Ruellia & Mexico & Herb \\
\hline 5 & Thunbergia grandiflora & Acanthaceae & Thunbergia & Asia & Liana \\
\hline \multirow[t]{2}{*}{6} & Adiantum capillus-veneris & $\begin{array}{l}\text { Adiantaceae } \\
\text { Adiantaceae }\end{array}$ & Adiantum & pantropical & Herb \\
\hline & & Agavaceae & & & \\
\hline 7 & Agave americana & Agavaceae & Agave & America & Herb \\
\hline \multirow[t]{2}{*}{8} & Agave sisalana & Agavaceae & Agave & North America & Herb \\
\hline & & Aizoaceae & & & \\
\hline 9 & Tetragonia tetragonioides & Aizoaceae & Tetragonia & Australia, Asia, South America & Herb \\
\hline \multirow[t]{2}{*}{10} & Trianthema portulacastrum & Aizoaceae & Trianthema & Tropical Africa and Asia & Herb \\
\hline & & Amaranthaceae & & & \\
\hline 11 & Achyranthes aspera & Amaranthaceae & Achyranthes & India, Vietnam, Philippines & Herb \\
\hline 12 & Alternanthera bettzickiana & Amaranthaceae & Alternanthera & America & Herb \\
\hline 13 & Alternanthera paronychioides & Amaranthaceae & Alternanthera & South America & Herb \\
\hline 14 & Alternanthera philoxeroides & Amaranthaceae & Alternanthera & South America & Herb \\
\hline 15 & Alternanthera sessilis & Amaranthaceae & Alternanthera & Vietnam, Malaysia, Philippines & Herb \\
\hline 16 & Amaranthus hybridus & Amaranthaceae & Amaranthus & America & Herb \\
\hline 17 & Amaranthus lividus & Amaranthaceae & Amaranthus & America & Herb \\
\hline
\end{tabular}


Amaranthus paniculatus

Amaranthus spinosus

Amaranthus tricolor

Amaranthus viridis

Celosia argentea

Celosia cristata

Gomphrena celosioides

Gomphrena globosa

Iresine herbstii

Hippeastrum rutilum

Hippeastrum vittatum

Narcissus tazetta

Zephyranthes candida

Zephyranthes grandiflora

Mangifera indica

Annona glabra

Annona squamosa

Coriandrum sativum

Daucus carota

Daucus carota var. sativa

Eryngium foetidum

\begin{abstract}
Amaranthaceae
Amaranthaceae

Amaranthaceae

Amaranthaceae

Amaranthaceae

Amaranthaceae

Amaranthaceae

Amaranthaceae

Amaranthaceae

Amaranthus

Amaranthus

Amaranthus

Amaranthus

Celosia

Celosia

Gomphrena

Gomphrena

Iresine
\end{abstract}

\section{Amaryllidaceae}

Amaryllidaceae

Amaryllidaceae

Amaryllidaceae

Amaryllidaceae

Amaryllidaceae

\section{Anacardiaceae}

Anacardiaceae

\section{Annonaceae}

Annonaceae

Annonaceae

$\begin{array}{lc}\text { Apiaceae } & \\ \text { Apiaceae } & \text { Coriandrum } \\ \text { Apiaceae } & \text { Daucus } \\ \text { Apiaceae } & \text { Daucus } \\ \text { Apiaceae } & \text { Eryngium }\end{array}$

\section{Hippeastrum Hippeastrum \\ Narcissus}

Zephyranthes

Zephyranthes

Mangifera

Annona

Annona

Eryngium
America

America

Asia

Africa

America

Asia

America

America

Brazil

South America

South America

Middle Europe, Mediterranean, West Asia

North America

North America

India

Tree

Tropical America

Tropical America

Tree

Shrub, Tree

Herb

Herb

Herb

Herb 
Catharanthus roseus Plumeria rubra Rauvolfia tetraphylla Thevetia peruviana

Caladium bicolor Dieffenbachia picta Pistia stratiotes

\section{Asclepias curassavica}

Ageratum conyzoides Ageratum houstonianum Ambrosia artemisiifolia Artemisia annua Artemisia verlotiorum Aster subulatus Bidens bipinnata Bidens pilosa

Bidens pilosa var. radiata Centipeda minima

Chrysanthemum coronarium

Conyza bonariensis

\section{Apocynaceae} Apocynaceae Apocynaceae Apocynaceae Apocynaceae

\section{Araceae}

Araceae

Araceae

Araceae

\section{Asclepiadaceae}

Asclepiadaceae

Asteraceae

Asteraceae

Asteraceae

Asteraceae

Asteraceae

Asteraceae

Asteraceae

Asteraceae

Asteraceae

Asteraceae

Asteraceae

Asteraceae

Asteraceae

\section{Catharanthus \\ Plumeria \\ Rauvolfia \\ Thevetia}

\section{Caladium}

Dieffenbachia

Pistia

Asclepias

Ageratum

Ageratum

Ambrosia

Artemisia

Artemisia

Aster

Bidens

Bidens

Bidens

Centipeda

Chrysanthemu

$\mathrm{m}$

Conyza
Africa

South America

Tropical America, Tropical Africa

Tropical America

\author{
South America \\ South America \\ Brazil
}

Latin America

Herb

Herb

Herb

Herb

Herb

Herb

Herb

Herb

Herb

Herb

Herb

North America

Pantropical

Mediterranean

Herb

America

Herb 
Conyza canadensis

Conyza sumatrensis

Coreopsis lanceolata

Coreopsis tinctoria

Cosmos bipinnata

Cosmos sulphureus

Crassocephalum crepidioides

Crossostephium Chinensis Dahlia pinnata

Elephantopus scaber

Elephantopus tomentosus Emilia sonchifolia

Erechthites hieracifolia

Erechthites valerianaefolia Erigeron annuus

Erigeron karvinskianus

Eupatorium odoratum

Eupatorium catarium

Galinsoga parviflora

Gnaphalium pensylvanicum

Gnaphalium polycaulon Helianthus annuus

Helianthus tuberosus Lactuca sativa

Leucanthemum vulgare Mikania cordata Mikania micrantha

Parthenium hysterophorus Silybum marianum

$\begin{array}{lc}\text { Asteraceae } & \text { Conyza } \\ \text { Asteraceae } & \text { Conyza } \\ \text { Asteraceae } & \text { Coreopsis } \\ \text { Asteraceae } & \text { Coreopsis } \\ \text { Asteraceae } & \text { Cosmos } \\ \text { Asteraceae } & \text { Cosmos } \\ \text { Asteraceae } & \text { Crassocephalu } \\ \text { Asteraceae } & \text { m } \\ \text { Asteraceae } & \text { Drossostephium } \\ \text { Asteraceae } & \text { Elephantopus } \\ \text { Asteraceae } & \text { Elephantopus } \\ \text { Asteraceae } & \text { Emilia } \\ \text { Asteraceae } & \text { Erechthites } \\ \text { Asteraceae } & \text { Erechthites } \\ \text { Asteraceae } & \text { Erigeron } \\ \text { Asteraceae } & \text { Erigeron } \\ \text { Asteraceae } & \text { Eupatorium } \\ \text { Asteraceae } & \text { Eupatorium } \\ \text { Asteraceae } & \text { Galinsoga } \\ \text { Asteraceae } & \text { Gnaphalium } \\ \text { Asteraceae } & \text { Gnaphalium } \\ \text { Asteraceae } & \text { Helianthus } \\ \text { Asteraceae } & \text { Helianthus } \\ \text { Asteraceae } & \text { Lactuca } \\ \text { Asteraceae } & \text { Leucanthemum } \\ \text { Asteraceae } & \text { Mikania } \\ \text { Asteraceae } & \text { Mikania } \\ \text { Asteraceae } & \text { Parthenium } \\ \text { Asteraceae } & \text { Silybum }\end{array}$

Asteracea

Asteraceae

Asteracea

Asteraceae

Asteracea

Asteraceae
North America

South America

North America

North America

North America

North America

\section{Africa}

America

Mexico

America

America

Pantropical

North America

South America

North America

Mexico, Panama

Tropical America

South America

South America

Warm America

Pantropical

America

North America

Mediterranean

$$
\text { Europe }
$$

Indonesia, LALaos, Vietnam

Central and South America

$$
\text { America }
$$

Europe, Asia, Africa
Herb

Herb

Herb

Herb

Herb

Herb

Herb

Herb, Shrub

Herb

Herb

Herb

Herb

Herb

Herb

Herb

Herb

Herb

Herb

Herb

Herb

Herb

Herb

Herb

Herb

Herb

Herb/Vine

Herb/Vine

Herb

Herb 


$\begin{array}{lc}89 & \text { Solidago canadensis } \\ 90 & \text { Soliva anthemifolia } \\ 91 & \text { Sonchus arvensis } \\ 92 & \text { Sonchus asper } \\ 93 & \text { Sonchus oleraceus } \\ 94 & \text { Spilanthes paniculata } \\ 95 & \text { Synedrella nodiflora } \\ 96 & \text { Tagetes erecta } \\ 97 & \text { Tagetes patula } \\ 98 & \text { Tithonia diversifolia } \\ 99 & \text { Tridax procumbens } \\ 100 & \text { Vernonia cinerea } \\ 101 & \text { Wedelia trilobata } \\ 102 & \text { Xanthium strumarium } \\ 103 & \text { Zinnia elegans }\end{array}$

Begonia cucullata Begonia semperflorens

$\begin{array}{lc}\text { Asteraceae } & \text { Solidago } \\ \text { Asteraceae } & \text { Soliva } \\ \text { Asteraceae } & \text { Sonchus } \\ \text { Asteraceae } & \text { Sonchus } \\ \text { Asteraceae } & \text { Sonchus } \\ \text { Asteraceae } & \text { Spilanthes } \\ \text { Asteraceae } & \text { Synedrella } \\ \text { Asteraceae } & \text { Tagetes } \\ \text { Asteraceae } & \text { Tagetes } \\ \text { Asteraceae } & \text { Tithonia } \\ \text { Asteraceae } & \text { Tridax } \\ \text { Asteraceae } & \text { Vernonia } \\ \text { Asteraceae } & \text { Wedelia } \\ \text { Asteraceae } & \text { Xanthium } \\ \text { Asteraceae } & \text { Zinnia }\end{array}$

Balsaminaceae

\section{Balsaminaceae}

Balsaminaceae

Impatiens

Impatiens

\section{Basellaceae}

Basellaceae

Basella

Begonia

Begoniacer

Begoniaceae

Begonia

Bignoniaceae

Bignoniaceae

Bignoniaceae
Macfadyena

Pyrostegia
North America

Oceania

Europe

Europe

Europe

Pantropical

America

North America (Mexico)

Mexico

Central and North America

America

Pantropical

America

Eurasia

Mexico

Asia

Africa

Herb

Herb

Tropical Asia

Herb

South America

Brazil

Herb

Herb

America

Liana

America

Herb

Herb

Herb

Herb

Herb

Herb

Herb

Herb

Herb

Herb

Herb

Herb

Herb

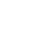

APPLIED ECOLOGY AND ENVIRONMENTAL RESEARCH 14(3): 637-677.

http://www.aloki.hu • ISSN 15891623 (Print) • ISSN 17850037 (Online)

DOI: http://dx.doi.org/10.15666/aeer/1403_637677

( ) 2016, ALÖKI Kft., Budapest, Hungary 
Brassica juncea

Brassica oleracea var. botrytis Brassica oleracea var. capitata Brassica rapa var. oleifera Capsella bursa-pastoris Cardamine flexuosa Lepidium virginicum Lobularia maritima Nasturtium officinale Raphanus sativus Rorippa heterophylla Sisymbrium altissimum

\author{
Epiphyllum oxypetalum \\ Hylocereus undatus \\ Opuntia dillenii \\ Pereskia aculeata
}

\section{Bixaceae}

Bixaceae

\section{Boraginaceae}

Boraginaceae

\section{Brassicaceae}

Brassicaceae

Brassicaceae

Brassicaceae

Brassicaceae

Brassicaceae

Brassicaceae

Brassicaceae

Brassicaceae

Brassicaceae

Brassicaceae

Brassicaceae

Brassicaceae

\section{Cactaceae}

Cactaceae

Cactaceae

Cactaceae

Cactaceae

\section{Cannaceae}

Cannaceae
Bixa

tropical America

Tree

Heliotropium

Thailand, Southeast Asia

Herb

Brassica
Brassica
Brassica
Brassica
Capsella
Cardamine
Lepidium
Lobularia
Nasturtium
Raphanus
Rorippa
Sisymbrium

Epiphyllum

Hylocereus

Opuntia

Pereskia

Canna

\section{Asia \\ Europe \\ Europe \\ Europe \\ Europe}

Northern Eurasia

North America

Mediterranean

Europe

Mediterranean

Asia

Europe

Mexico

America

Tropical America

America

Herb

Herb

Herb

Herb

Herb

Herb

Herb

Herb

Herb

Herb

Herb

Herb

Shrub

Liana

Herb

Liana

tropical America

Herb 


\section{Carica papaya}

Arenaria serpyllifolia Stellaria media Stellaria uliginosa

Casuarina equisetifolia

Chenopodium album Chenopodium ambrosioides

Quisqualis indica

\section{Zebrina pendula}

Argyreia acuta

Argyreia nervosa

Cuscuta japonica

Ipomoea alba

Ipomoea aquatica

\section{Capparidaceae}

Capparidaceae

Cleome

Africa

Herb

\section{Caricaceae}

Caricaceae

Carica

Tropical America

Tree

\section{Caryophyllaceae}

Caryophyllaceae

Caryophyllaceae

Caryophyllaceae

Arenaria

Stellaria

Stellaria

\section{Casuarinaceae}

Casuarinaceae

Chenopodiaceae

Chenopodiaceae

Chenopodiaceae

\section{Combretaceae}

Combretaceae

\section{Commelinaceae}

Commelinaceae

\section{Convolvulaceae}

Convolvulaceae

Convolvulaceae

Convolvulaceae

Convolvulaceae

Convolvulaceae

\section{Casuarina}

Chenopodium

Chenopodium

Quisqualis

Zebrina

Argyreia

Argyreia

Cuscuta

Ipomoea

Ipomoea

\section{Europe}

Cosmopolitan

Northern Eurasia

Australia

Tree

Herb

Herb

Herb

Herb

Herb

America
Shrub

Europe, Asia

Mexico

Herb

Liana

Asia

India

Asia

Liana

America

America
Herb/Vine

Herb/Vine

Herb/Vine 


Ipomoea batatas
Ipomoea cairica
Ipomoea carnea scbsp. fistulosa
Ipomoea indica
Ipomoea mauritiana
Ipomoea nil
Ipomoea purpurea
Ipomoea quamoclit
Ipomoea triloba

Bryophyllum pinnatum Kalanchoe tubiflora

Kalanchoe verticillata Sedum mexicanum

\section{Momordica charantia} Sechium edule

Sphaeropteris lepifera

Cyperus alternifolius subsp. flabelliformis

Cyperus rotundus

Schoenoplectus mucronatus

$\begin{array}{ll}\text { Convolvulaceae } & \text { Ipomoea } \\ \text { Convolvulaceae } & \text { Ipomoea } \\ \text { Convolvulaceae } & \text { Ipomoea } \\ \text { Convolvulaceae } & \text { Ipomoea } \\ \text { Convolvulaceae } & \text { Ipomoea } \\ \text { Convolvulaceae } & \text { Ipomoea } \\ \text { Convolvulaceae } & \text { Ipomoea } \\ \text { Convolvulaceae } & \text { Ipomoea } \\ \text { Convolvulaceae } & \text { Ipomoea }\end{array}$

\section{Crassulaceae}

Crassulaceae

Crassulaceae

Crassulaceae

Crassulaceae

Cucurbitaceae

Cucurbitaceae

Cucurbitaceae
Momordica
Sechium
Bryophyllum
Kalanchoe
Kalanchoe
Sedum

\section{Cyatheaceae}

Cyatheaceae

Sphaeropteris

\section{Cyperaceae}

Cyperaceae
Cyperaceae
Cyperaceae

Cyperus

Cyperus

Schoenoplectus
America

Europe

Tropical America

South America

America

America

Tropical America

Tropical America

Tropical America

Africa
Africa
Africa

Mexico, America

Palaeotropics

America

Southeast Asia

Tree

Herb

Herb

Herb

\section{Herb}

Shrub

Herb

Herb

Herb

Herb
Herb/Vine

Herb/Vine

Herb/Vine

Herb/Vine

Herb/Vine

Herb/Vine

Herb/Vine

Herb/Vine

Herb/Vine

\section{Elatinaceae}

Africa
Asia
cosmopolitan




\section{Equisetum arvense}

Equisetum ramosissimum
Codiaeum variegatum Euphorbia cyathophora Euphorbia graminea Euphorbia hirta

Euphorbia marginata Euphorbia milii

Euphorbia prostrata

Excoecaria tirucalli

Jatropha curcas

Manihot esculenta

Pedilanthu tithymaloides Phyllanthus niruri

Phyllanthus tenellus

Ricinus communis

\section{Acacia farnesiana} Aeschynomene indica Arachis duranensis Arachis hypogaea Caesalpinia pulcherrima Cajanus cajan Canavalia gladiata

Elatinaceae

Elatine

America

Herb

\section{Equisetaceae}

Equisetaceae

Equisetaceae

\section{Euphorbiaceae}

\section{Euphorbiaceae}

Euphorbiaceae

Euphorbiaceae

Euphorbiaceae

Euphorbiaceae

Euphorbiaceae

Euphorbiaceae

Euphorbiaceae

Euphorbiaceae

Euphorbiaceae

Euphorbiaceae

Euphorbiaceae

Euphorbiaceae

Euphorbiaceae

\section{Fabaceae}

Fabaceae

Fabaceae

Fabaceae

Fabaceae

Fabaceae

Fabaceae

Fabaceae

\section{Equisetum \\ Equisetum}

Codiaeum

Euphorbia

Euphorbia

Euphorbia

Euphorbia

Euphorbia

Euphorbia

Excoecaria

Jatropha

Manihot

Pedilanthu

Phyllanthus

Phyllanthus

Ricinus

Acacia

Aeschynomene

Arachis

Arachis

Caesalpinia

Cajanus

Canavalia
North temperate Zone

Asia

Herb

Herb

Malay Peninsula To Oceania
Central America, South America
South Mexico, Central and South America
Tropical
North America
Africa
Tropical America
Africa

Shrub, Tree

Herb

Herb

Herb

Herb

Liana

Herb

Herb

America

South America

Tropical America
America
America
Africa

Shrub, Tree

Shrub

Herb, Shrub

Herb

Herb

Herb

Shrub

Herb

Herb

Herb

Shrub, Tree

Shrub

Herb/Vine 

patellaria var. glabrata

Chamaecrista mimosoides

Clitoria ternatea

Crotalaria pallida

Crotalaria zanzibarica

Derris elliptica

Desmodium tortuosum

Dolichos lablab

Erythrina corallodendron

Indigofera suffruticosa

Leucaena leucocephala

Lotus corniculatus

Medicago sativa

Mimosa bimucronata

Mimosa invisa

Mimosa pudica

Pachyrhizus erosus

Pithecellobium dulce

Pueraria phaseoloides Senna alata

Senna occidentalis

Senna siamea

Senna occidentalis var. sophera

Senna tora

Sesbania cannabina

Stylosanthes guianensis

$\begin{array}{lc}\text { Fabaceae } & \text { Cassia } \\ \text { Fabaceae } & \text { Cassia } \\ \text { Fabaceae } & \text { Centrosema } \\ \text { Fabaceae } & \text { Chamaecrista } \\ \text { Fabaceae } & \text { Chamaecrista } \\ \text { Fabaceae } & \text { Clitoria } \\ \text { Fabaceae } & \text { Crotalaria } \\ \text { Fabaceae } & \text { Crotalaria } \\ \text { Fabaceae } & \text { Derris } \\ \text { Fabaceae } & \text { Desmodium } \\ \text { Fabaceae } & \text { Dolichos } \\ \text { Fabaceae } & \text { Erythrina } \\ \text { Fabaceae } & \text { Indigofera } \\ \text { Fabaceae } & \text { Leucaena } \\ \text { Fabaceae } & \text { Lotus } \\ \text { Fabaceae } & \text { Medicago } \\ \text { Fabaceae } & \text { Mimosa } \\ \text { Fabaceae } & \text { Mimosa } \\ \text { Fabaceae } & \text { Mimosa } \\ \text { Fabaceae } & \text { Pachyrhizus } \\ \text { Fabaceae } & \text { Pithecellobium } \\ \text { Fabaceae } & \text { Pueraria } \\ \text { Fabaceae } & \text { Senna } \\ \text { Fabaceae } & \text { Senna } \\ \text { Fabaceae } & \text { Senna } \\ \text { Fabaceae } & \text { Senna } \\ \text { Fabaceae } & \text { Senna } \\ \text { Fabaceae } & \text { Sesbania } \\ \text { Fabaceae } & \text { Stylosanthes } \\ & \end{array}$

\section{America \\ America \\ America}

Tropical America

America

India

Ethiopia

South America

Tropical Asia, India

America

Asia

South America

America

America

Europe, Asia, Africa

Asia

America

America

America

America

Central America

Indonesia,Malaysia

America

America

Burma to Malaysia

$$
\text { Aisa }
$$

Asia (India)

Asia (India)

South America
Shrub

Shrub

Herb/Vine

Herb

Herb, Shrub Herb

Herb

Herb, Shrub

Liana

Herb

Herb/Vine

Shrub

Herb, Shrub

Shrub

Herb

Herb

Shrub

Herb

Herb, Shrub

Herb/Vine

Tree

Herb/Vine

Shrub

Herb, Shrub

Tree

Shrub

Herb

Herb

Herb, Shrub 


\section{Tamarindus indica \\ Tephrosia candida \\ Trifolium repens \\ Zornia gibbosa}

\section{Geranium carolinianum}

Pityrogramma calomelanos

Hyptis brevipes

Hyptis rhomboidea

Hyptis suaveolens

Mentha haplocalyx

Mentha spicata

Ocimum basilicum

Perilla frutescens

Salvia coccinea

Aloe vera var.chinese Asparagus densiflorus $c v$.

$$
\text { densiflorus }
$$

Asparagus setaceus

Cordyline fruticosa

Gladiolus gandavensis

$\begin{array}{lc}\text { Fabaceae } & \text { Tamarindus } \\ \text { Fabaceae } & \text { Tephrosia } \\ \text { Fabaceae } & \text { Trifolium } \\ \text { Fabaceae } & \text { Zornia }\end{array}$

\section{Geraniaceae}

Geraniaceae

Geranium

Hemionitidaceae

Hemionitidaceae

Pityrogramma

America

$\begin{array}{lc}\text { Lamiaceae } & \\ \text { Lamiaceae } & \text { Hyptis } \\ \text { Lamiaceae } & \text { Hyptis } \\ \text { Lamiaceae } & \text { Hyptis } \\ \text { Lamiaceae } & \text { Mentha } \\ \text { Lamiaceae } & \text { Mentha } \\ \text { Lamiaceae } & \text { Ocimum } \\ \text { Lamiaceae } & \text { Perilla } \\ \text { Lamiaceae } & \text { Salvia }\end{array}$

Liliaceae

Liliaceae

Liliaceae

Liliaceae

Liliaceae

Asparagus

Asparagus

Cordyline

America

\author{
Africa \\ Asia \\ Europe, North Africa \\ America
}

\section{Iridaceae}

Iridaceae
Gladiolus

\section{America}

America

America

Asia

Europe

Africa, Asia

Asia

America

Southern Africa

South Africa

Africa

uncertain
Herb

Tree

Herb, Shrub

Herb

Herb

Herb

Herb

Herb

Herb

Herb

Herb

Herb

Herb

Herb, Shrub

Herb/Vine

Shrub

Herb

Herb 
Cuphea balsamona

Lythrum salicaria

Abelmoschus moschatus

Bombax malabarica

Corchorus capsularis

Malva verticillata

Malvastrum coromandelianum Sida acuta

Sida cordata Sida rhombifolia

Urena lobata

Urena procumbens

Waltheria indica

Mollugo verticillata

Musa basjoo

Eucalyptus robusta

Psidium guajava

Syzygium jambos

\section{Lythraceae}

Lythraceae

Lythraceae

Cuphea

Lythrum

Malvaceae

Malvaceae

Malvaceae

Malvaceae

Malvaceae

Malvaceae

Malvaceae

Malvaceae

Malvaceae

Malvaceae

Malvaceae

Malvaceae

Abelmoschus
Bombax
Corchorus
Malva
Malvastrum
Sida
Sida
Sida
Urena
Urena
Waltheria

Molluginaceae

Molluginaceae

Mollugo

Musa

Musacea

\section{Myrtaceae}

Myrtaceae

Myrtaceae

Myrtaceae

\section{Southwest and Central Asia}

$\begin{array}{cc}\text { America } & \text { Herb } \\ \text { Europe } & \text { Herb }\end{array}$

South Asia

Herb

South Africa

Subtropics

Asia

America

Asia

Pantropic

Pantropic

Pantropic

Pantropic

America

Herb

Herb

\section{Tree}

Herb

Herb

Herb, Shrub Herb

Herb, Shrub Herb

Herb, Shrub

Herb, Shrub

Herb, Shrub

\section{Herb}

Herb

Australia

America

Southest Asia
Tree Shrub, Tree

Tree 
Bougainvillea glabra Bougainvillea spectabilis Mirabilis jalapa

Nymphaea alba

\section{Jasminum sambac}

Ludwigia hyssopifolia Oenothera drummondii

\section{Oxalis corniculata}

Oxalis corymbosa

Elaeis guineensis

Passiflora caerulea

Passiflora edulis

Passiflora foetida

Phytolacca americana

\section{Nyctaginaceae}

Nyctaginaceae

Nyctaginaceae

Nyctaginaceae
Bougainvillea
Bougainvillea
Mirabilis

Brazil

$$
\text { Brazil }
$$

South America

Shrub

Shrub

Herb

\section{Nymphaeaceae}

Nymphaeaceae

Nymphaea

North Afica, Eurasia

Herb

\section{Oleaceae}

Oleaceae

\section{Onagraceae}

Onagraceae

Onagraceae

Jasminum

India

Herb

\section{Oxalidaceae}

Oxalidaceae

Oxalidaceae

Ludwigia
Oenothera

America

America

Herb

Herb

\section{Palmaceae}

\section{Oxalis}

Oxalis

South America, Afica

Herb America

Herb
Palmaceae

\section{Passifloraceae}

Passifloraceae

Passifloraceae

Passifloraceae

\section{Phytolaccaceae}

Phytolaccaceae

Elaeis

Tropical Africa

Shrub
Passiflora

Passiflora

Passiflora
Brazil and Netherlands antilles

Latin America
Herb/Vine

Herb/Vine

Herb/Vine 
Peperomia pellucida Piper betle

Pittosporum tobira

Plantago major

Alopecurus aequalis Alopecurus japonicus Arundo donax Axonopus compressus Brachiaria eruciformis Cenchrus echinatus Chloris barbata Coix lacryma-jobi Digitaria ciliaris Digitaria sanguinalis Echinochloa crusgalli Eleusine indica

Eragrostis cillaris

Eragrostis perennans Melinis repens

Panicum maximum Panicum repens

\section{Piperaceae}

Piperaceae

Piperaceae

Peperomia

Piper

America

Tropical Asia, Africa

Herb

Pittosporaceae

Pittosporaceae

Pittosporum

America

Shrub, Tree

\section{Plantaginaceae}

Plantaginaceae

Plantago

Cosmopolitan

Herb

\section{Poaceae}

Poaceae

Poaceae

Poaceae

Poaceae

Poaceae

Poaceae

Poaceae

Poaceae

Poaceae

Poaceae

Poaceae

Poaceae

Poaceae

Poaceae

Poaceae

Poaceae

Poaceae

Alopecurus
Alopecurus
Arundo
Axonopus
Brachiaria
Cenchrus
Chloris
Coix
Digitaria
Digitaria
Echinochloa
Eleusine
Eragrostis
Eragrostis
Melinis
Panicum
Panicum

\section{North America Asia \\ Mediterranean \\ America \\ Pantropics \\ America}

Tropical America

Tropical Asia

Tropics, Subtropics Europe

Europe, Asia

$$
\text { Asia }
$$

Paleotropics

Cosmopolitan

Africa

Africa

Brazil
Herb

Herb

Herb

Herb

Herb

Herb

Herb

Herb

Herb

Herb

Herb

Herb

Herb

Herb

Herb

Herb

Herb 

Paspalum conjugatum
Paspalum distichum

Paspalum urvillei

Pennisetum purpureum Poa annua

Setaria geniculata Setaria glauca

Setaria pallidifusca

Setaria palmifolia

Setaria viridis

\section{Antigonon leptopus}

Homalocladium platycladum

Polygonum aviculare

Rumex acetosella

Rumex crispus

Eichhornia crassipes

Portulaca grandiflora

Portulaca oleracea

Portulaca pilosa

Talinum paniculatum

Punica granatum

$\begin{array}{lc}\text { Poaceae } & \text { Paspalum } \\ \text { Poaceae } & \text { Paspalum } \\ \text { Poaceae } & \text { Paspalum } \\ \text { Poaceae } & \text { Pennisetum } \\ \text { Poaceae } & \text { Poa } \\ \text { Poaceae } & \text { Setaria } \\ \text { Poaceae } & \text { Setaria } \\ \text { Poaceae } & \text { Setaria } \\ \text { Poaceae } & \text { Setaria } \\ \text { Poaceae } & \text { Setaria }\end{array}$

Antigonon

Polygonaceae

Polygonaceae

Polygonaceae

Polygonaceae

Polygonaceae

Polygonaceae

Homalocladium

Polygonum

Rumex

Rumex

\section{Pontederiaceae}

Pontederiaceae

Portulacaceae

Portulacaceae

Portulacaceae

Portulacaceae

Portulacaceae

\section{Punicaceae}

Punicaceae
Eichhornia

Portulaca

Portulaca

Portulaca

Talinum
America

Tropical America

Tropical America

Africa

Europe

Asia, Europe

Eurasia, America, Australia

Southern Asia, Australia

Africa

Eurasia

Central America

Oceania

Asia

Eurasia

Eurasia

America

Herb

Herb

Herb

Herb

Herb

Herb

Herb

Herb

Herb

Herb

Herb

Herb

Herb

Herb

Herb

Liana

Shrub

Herb

Herb

Herb

Cosmopolitan

America

Shrub, Tree 


\section{Borreria articularis Borreria latifolia Galium aparine}

Cardiospermum halicacabum

$$
\begin{aligned}
& \text { Scoparia dulcis } \\
& \text { Striga asiatica } \\
& \text { Torenia fournieri } \\
& \text { Veronica peregrina } \\
& \text { Veronica persica } \\
& \text { Veronica polita }
\end{aligned}
$$

322
323
324
325
326
327
328

\section{Capsicum annuum}

Capsicum annuum var. conoides Datura metel

Datura stramonium Lycopersicon esculentum Nicandra physaloides Petunia hybrida

\section{Ranunculaceae}

Ranunculaceae

Ranunculus

Aisa

Herb

Rubiaceae

Rubiaceae

Borreria

Rubiaceae

Borreria

India

Rubiaceae

Galium

\section{Rutaceae}

Rutaceae

\section{Sapindaceae}

Sapindaceae

Cardiospermum

Citrus

Uncertain

Tree

\section{Scrophulariaceae}

Scrophulariaceae

Scrophulariaceae

Scrophulariaceae

Scrophulariaceae

Scrophulariaceae

Scrophulariaceae

Scoparia
Striga
Torenia
Veronica
Veronica
Veronica

\section{Solanaceae}

Solanaceae

Solanaceae

Solanaceae

Solanaceae

Solanaceae

Solanaceae

Solanaceae

Capsicum
Capsicum
Datura
Datura
Lycopersicon
Nicandra
Petunia

America

Herb/Vine 


\begin{tabular}{|c|c|c|c|c|c|}
\hline 329 & Physalis angulata & Solanaceae & Physalis & America & Herb \\
\hline 330 & Physalis minima & Solanaceae & Physalis & Tropical Asia & Herb \\
\hline 331 & Solanum americanum & Solanaceae & Solanum & South America & Herb \\
\hline 332 & Solanum capsicoides & Solanaceae & Solanum & Brazil & Herb, Shrub \\
\hline 333 & Solanum erianthum & Solanaceae & Solanum & America & Tree \\
\hline 334 & Solanum melongena & Solanaceae & Solanum & South America & Herb \\
\hline 335 & Solanum pseudocapsicum & Solanaceae & Solanum & Brazil & Herb \\
\hline 336 & Solanum surattense & Solanaceae & Solanum & Brazil & Herb, Shrub \\
\hline 337 & Solanum torvum & Solanaceae & Solanum & America & Shrub \\
\hline 338 & Tropaeolum majus & $\begin{array}{l}\text { Tropaeolaceae } \\
\text { Tropaeolaceae }\end{array}$ & Tropaeolum & South America & Herb \\
\hline \multirow[t]{2}{*}{339} & Pilea microphylla & $\begin{array}{l}\text { Urticaceae } \\
\text { Urticaceae }\end{array}$ & Pilea & South America & Herb \\
\hline & & Verbenaceae & & & \\
\hline 340 & Clerodendrum philippinum & Verbenaceae & Clerodendrum & Asia & Shrub \\
\hline 341 & Duranta erecta & Verbenaceae & Duranta & Latin America & Shrub \\
\hline 342 & Lantana camara & Verbenaceae & Lantana & America & Shrub \\
\hline 343 & Lantana montevidensis & Verbenaceae & Lantana & Latin America & Shrub \\
\hline 344 & Phyla nodiflora & Verbenaceae & Phyla & America & Herb \\
\hline \multirow[t]{2}{*}{345} & Stachytarpheta jamaicensis & Verbenaceae & Stachytarpheta & Central and South America & Herb \\
\hline & & Zingiberaceae & & & \\
\hline 346 & Alpinia officinarum & Zingiberaceae & Alpinia & South Asia & Tree \\
\hline 347 & Curcuma domestica & Zingiberaceae & Curcuma & India & Herb \\
\hline 348 & Hedychium coronarium & Zingiberaceae & Hedychium & Himalaya & Herb \\
\hline 349 & Zingiber officinale & Zingiberaceae & Zingiber & Tropical Asia & Herb \\
\hline
\end{tabular}


Table S5. Checklist of invasive plant species in Shenzhen.

\begin{tabular}{|c|c|c|c|c|c|}
\hline Code & Species & Family & Genus & Geographic origin & Life form \\
\hline & & Amaranthaceae & & & \\
\hline 1 & Alternanthera philoxeroides & Amaranthaceae & Alternanthera & South America & Herb \\
\hline 2 & Amaranthus hybridus & Amaranthaceae & Amaranthus & America & Herb \\
\hline 3 & Amaranthus paniculatus & Amaranthaceae & Amaranthus & America & Herb \\
\hline 4 & Amaranthus spinosus & Amaranthaceae & Amaranthus & America & Herb \\
\hline 5 & Amaranthus tricolor & Amaranthaceae & Amaranthus & Asia & Herb \\
\hline 6 & Amaranthus viridis & Amaranthaceae & Amaranthus & Africa & Herb \\
\hline \multirow[t]{2}{*}{7} & Gomphrena celosioides & Amaranthaceae & Gomphrena & America & Herb \\
\hline & & Apiaceae & & & \\
\hline 8 & Coriandrum sativum & Apiaceae & Coriandrum & Mediterranean & Herb \\
\hline 9 & Daucus carota & Apiaceae & Daucus & Asia & Herb \\
\hline 10 & Eryngium foetidum & Apiaceae & Eryngium & America & Herb \\
\hline \multirow{3}{*}{11} & & Apocynaceae & & & \\
\hline & Catharanthus roseus & Apocynaceae & Catharanthus & Africa & Herb \\
\hline & & Araceae & & & \\
\hline 12 & Pistia stratiotes & Araceae & Pistia & Brazil & Herb \\
\hline \multirow[t]{2}{*}{13} & Asclepias curassavica & $\begin{array}{l}\text { Asclepiadaceae } \\
\text { Asclepiadaceae }\end{array}$ & Asclepias & Latin America & Herb \\
\hline & Ageratum conyzoides & $\begin{array}{c}\text { Asteraceae } \\
\text { Asteraceae }\end{array}$ & Ageratum & Central and South America & \\
\hline 15 & Ageratum houstonianum & Asteraceae & Ageratum & North America & Liana \\
\hline 16 & Ambrosia artemisiifolia & Asteraceae & Ambrosia & North America & \\
\hline 17 & Aster subulatus & Asteraceae & Aster & North America & \\
\hline
\end{tabular}


Bidens bipinnata

Chrysanthemum coronarium

Conyza bonariensis

Conyza canadensis

Conyza sumatrensis

Coreopsis lanceolata

Coreopsis tinctoria

Cosmos bipinnata

Crassocephalum crepidioides

Crossostephium Chinensis

Erechthites hieracifolia

Erechthites valerianaefolia

Erigeron annuи

Eupatorium odoratum

Galinsoga parviflora

Gnaphalium pensylvanicum

Helianthus tuberosus

Leucanthemum vulgare

Mikania micrantha

Parthenium hysterophorus

Silybum marianum

Solidago canadensis

Soliva anthemifolia

Sonchus asper

Sonchus oleraceus

Synedrella nodiflora

Tagetes erecta

Tagetes patula

Tithonia diversifolia

Tridax procumbens

$\begin{array}{lc}\text { Asteraceae } & \text { Bidens } \\ \text { Asteraceae } & \text { Chrysanthemum } \\ \text { Asteraceae } & \text { Conyza } \\ \text { Asteraceae } & \text { Conyza } \\ \text { Asteraceae } & \text { Conyza } \\ \text { Asteraceae } & \text { Coreopsis } \\ \text { Asteraceae } & \text { Coreopsis } \\ \text { Asteraceae } & \text { Cosmos } \\ \text { Asteraceae } & \text { Crassocephalum } \\ \text { Asteraceae } & \text { Crossostephium } \\ \text { Asteraceae } & \text { Erechthites } \\ \text { Asteraceae } & \text { Erechthites } \\ \text { Asteraceae } & \text { Erigeron } \\ \text { Asteraceae } & \text { Eupatorium } \\ \text { Asteraceae } & \text { Galinsoga } \\ \text { Asteraceae } & \text { Gnaphalium } \\ \text { Asteraceae } & \text { Helianthus } \\ \text { Asteraceae } & \text { Leucanthemum } \\ \text { Asteraceae } & \text { Mikania } \\ \text { Asteraceae } & \text { Parthenium } \\ \text { Asteraceae } & \text { Silybum } \\ \text { Asteraceae } & \text { Solidago } \\ \text { Asteraceae } & \text { Soliva } \\ \text { Asteraceae } & \text { Sonchus } \\ \text { Asteraceae } & \text { Sonchus } \\ \text { Asteraceae } & \text { Synedrella } \\ \text { Asteraceae } & \text { Tagetes } \\ \text { Asteraceae } & \text { Tagetes } \\ \text { Asteraceae } & \text { Tithonia } \\ \text { Asteraceae } & \text { Tridax } \\ & \end{array}$

East Asia

Herb

Mediterranean

America

North America

South America

North America

North America

North America

Africa

America

North America

South America

North America

Tropical America

South America

Warm America

Europe

North America

America

Central and South America

Europe, Asia, Africa

North America

Oceania

Europe

Europe

America

North America（Mexico）

Mexico

Central and North America America

Herb

Herb

Herb

Herb

Herb

Herb

Herb

Herb

Herb

Herb

Herb

Herb

Herb

Herb

Herb, Shrub

Herb

Herb

Herb

Herb

Herb

Herb

Herb

Herb/Vine

Herb

Herb 
Macfadyena unguis-cati

$$
\text { Lepidium virginicum }
$$

Chenopodium ambrosioides

Ipomoea cairica

Ipomoea indica

Ipomoea nil

Ipomoea purpurea

Ipomoea triloba

Ricinus communis

Acacia farnesiana

Chamaecrista mimosoides
Asteraceae

Wedelia

America

Herb

\section{Bignoniaceae}

Bignoniaceae

Macfadyena

America

\section{Brassicaceae}

Brassicaceae

Lepidium

North America

Herb

Cactaceae

Cactaceae

Chenopodiaceae

Chenopodiaceae

Opuntia

Tropical America

Herb

\section{Convolvulaceae}

Convolvulaceae

Convolvulaceae

Convolvulaceae

Convolvulaceae

Convolvulaceae

\section{Crassulaceae}

Crassulaceae

\section{Euphorbiaceae}

Euphorbiaceae

Euphorbiaceae

Euphorbiaceae

Euphorbiaceae

Chenopodium

America

Herb
Fabaceae

Fabaceae

Fabaceae

\section{Ipomoea \\ Ipomoea \\ Ipomoea \\ Ipomoea \\ Ipomoea}

Bryophyllum

Euphorbia

Euphorbia

Jatropha

Ricinus

Acacia

Chamaecrista

\section{Europe \\ South America \\ America \\ Tropical America \\ Tropical America}

Africa

Central America, South America

North America

America

Africa

America

America
Herb/Vine

Herb/Vine

Herb/Vine

Herb/Vine

Herb/Vine

Herb

Herb

Herb

Shrub, Tree

Herb

Shrub

Herb, Shrub 
Crotalaria zanzibarica Indigofera suffruticosa Leucaena leucocephala Medicago sativa Mimosa bimucronata

Mimosa invisa

Mimosa pudica Senna alata

Senna occidentalis Senna tora Trifolium repens

Geranium carolinianum

$$
\begin{gathered}
\text { Hyptis brevipes } \\
\text { Hyptis rhomboidea } \\
\text { Hyptis suaveolens }
\end{gathered}
$$

Cuphea balsamona

\section{Malvastrum coromandelianum} Waltheria indica

Eucalyptus robusta Syzygium jambos

$\begin{array}{lc}\text { Fabaceae } & \text { Crotalaria } \\ \text { Fabaceae } & \text { Indigofera } \\ \text { Fabaceae } & \text { Leucaena } \\ \text { Fabaceae } & \text { Medicago } \\ \text { Fabaceae } & \text { Mimosa } \\ \text { Fabaceae } & \text { Mimosa } \\ \text { Fabaceae } & \text { Mimosa } \\ \text { Fabaceae } & \text { Senna } \\ \text { Fabaceae } & \text { Senna } \\ \text { Fabaceae } & \text { Senna } \\ \text { Fabaceae } & \text { Trifolium }\end{array}$

\section{Geraniaceae}

Geraniaceae

Geranium

\section{Labitae}

$\begin{array}{ll}\text { Lamiaceae } & \text { Hyptis } \\ \text { Lamiaceae } & \text { Hyptis } \\ \text { Lamiaceae } & \text { Hyptis }\end{array}$

\section{Lythraceae} Lythraceae

\section{Malvaceae}

Malvaceae

Malvaceae

\section{Malvastrum} Waltheria

\section{Myrtaceae \\ Myrtaceae \\ Myrtaceae}

Eucalyptus

Syzygium

\section{South America}

America

America

$$
\text { Asia }
$$

America

America

America

America

America

Burma to Malaysia

Europe, North Africa

America

America

America

America

America

America

America

Australia

Southest Asia
Herb, Shrub Herb, Shrub Shrub Herb Shrub Herb Herb, Shrub Shrub

Herb, Shrub

Tree

Herb

Herb

Herb

Herb

Herb

Herb

Herb, Shrub Herb, Shrub

Tree

Tree 
Paspalum conjugatum

Pennisetum purpureum

Eichhornia crassipes

\section{Nyctaginaceae}

Nyctaginaceae

\section{Onagraceae}

Onagraceae

\section{Oxalidaceae}

Oxalidaceae

\section{Passifloraceae}

Passifloraceae

\section{Phytolaccaceae}

Phytolaccaceae

\section{Piperaceae}

Piperaceae

\section{Poaceae}

Poaceae

Poaceae

Poaceae

Poaceae

Poaceae

Poaceae

Poaceae
Pontederiaceae

\section{Pontederiaceae}

Mirabilis

Oenothera

Passiflora

Latin America

Herb/Vine

Phytolacca

North America

Axonopus

Paspalum

Pennisetum

Eichhornia
America

Herb

America

Herb

Herb

America

Herb

America

Herb

America

Africa

Africa

Brazil

America

Africa

Herb

Herb

Herb

Herb

Herb

Herb

Herb

America 
Pilea microphylla

\section{Datura metel \\ Datura stramonium}

Nicandra physaloides

Physalis angulata

Solanum erianthum

Solanum surattense

Solanum torvum

\begin{tabular}{cc}
114 & Duranta erecta \\
115 & Lantana camara \\
116 & Lantana montevidensis \\
117 & Stachytarpheta jamaicensis \\
\hline
\end{tabular}

\section{Portulacaceae}

Portulacaceae

Portulacaceae

Rubiaceae

Rubiaceae

\section{Scrophulariaceae}

Scrophulariaceae

Scrophulariaceae

Scrophulariaceae

Scrophulariaceae

\section{Solanaceae}

Solanaceae

Solanaceae

Solanaceae

Solanaceae

Solanaceae

Solanaceae

Solanaceae

Urticaceae

Urticaceae

Verbenaceae

Verbenaceae

Verbenaceae

Verbenaceae

Verbenaceae

\section{Portulaca \\ Talinum}

Borreria

Scoparia

Veronica

Veronica

Veronica

\section{Datura \\ Datura \\ Nicandra \\ Physalis \\ Solanum \\ Solanum \\ Solanum}

Pilea
Tropical America

America

South America

North America

America

Asia

West Asia, Europe

America

America

North America

South America

America

America

Brazil

America

South America

Herb

Herb

Herb

Herb

Herb

Herb

Herb

Herb

Herb

Herb

Herb

Herb Tree

Shrub
Herb, Shrub

Herb, Shrub

Latin America

Shrub

\section{Duranta}

America

Shrub

Lantana

Latin America

Stachytarpheta 